\title{
Mid- to late-Holocene environmental evolution of the Loire estuary as observed from sedimentary characteristics and benthic foraminiferal assemblages
}

\author{
Durand M. ${ }^{1,{ }^{*}}$, Mojtahid M. ${ }^{1}$, Maillet G.M. ${ }^{1}$, Proust J.-N. ${ }^{2}$, Lehay D. ${ }^{3}$, Ehrhold Axel ${ }^{4}$, Barré A. ${ }^{1}$, \\ Howa H. ${ }^{1}$
}

${ }^{1}$ LPG-BIAF UMR-CNRS 6112, University of Angers, UFR Sciences, 2 bd Lavoisier, 49045 Angers

Cedex 01, France

2 UMR 6118 Géosciences CNRS, Université de Rennes 1, Campus de Beaulieu, 35042 Rennes Cedex, France

${ }^{3}$ Grand Port Maritime Nantes Saint-Nazaire, Pôle Environnement, 18 quai Ernest Renaud BP 18609, 44186 NANTES Cedex 4, France

${ }^{4}$ IFREMER Brest, Pointe du Diable, 29280 Plouzané, France

* Corresponding author : M. Durand, email address : matthieu.durand@univ-angers.fr

\begin{abstract}
:
We used sedimentological and foraminiferal characteristics of four sedimentary cores, supported by paleogeographical and historical data, to reconstruct the depositional history of the inner Loire estuary (Near Saint-Nazaire, France) and the response of benthic foraminifera to the mid- to late-Holocene marine flooding of the incised valley. These were further used to evaluate the consequent changes in estuarine morphological and hydro-sedimentary patterns during this time period. Our results described significant changes in hydro-sedimentary dynamics over the past $~ 6 \mathrm{kyrs}$ BP. At our location, these changes expressed the combined influence of marine (e.g., tide, storm waves) and fluvial dynamics (e.g., floods), which are linked, on a broader scale, to sea-level variations and the regional climate regime. Three main periods stand out: (1) from 6.0 to $~ 2.5 \mathrm{kyrs} B P$, when the sea-level rise slowed down, a large brackish bay extended over and around the study area. The fine-grained tidal rythmites recorded north of the Bilho bank (the main tidal bar located in our study area) indicated a calm depositional environment, protected from the main riverine influence. The presence of thick flood deposits from $\sim 5.4$ to $\sim 4.0$ kyrs BP near the Bilho bank indicates further the dominance of humid conditions. (2) From $\sim 2.5$ kyrs BP to $\sim 1850 \mathrm{CE}$ (pre-industrial state), sea-level stabilized at its present value, and the pre-existing bay was progressively infilled. North of the Bilho bank, near a major mudflat (Méan), the generally homogenous sedimentation composed of silty muds rich in organic matter indicated a sheltered environment; the main water flow channel being located south of the Bilho bank. Within this overall homogenous sedimentation, foraminiferal assemblages described rather accurately the progressive infilling of the valley (indicated by a decrease in the proportions of outer estuarine species), accompanied with the channelization of the main entering marine currents (tide, storm waves) (indicated by an increase in the proportions of transported species from the adjacent upper continental shelf), and finally the buildup of the Méan mudflat and the stabilization of the environment to its present day configuration (indicated by the dominance of autochthonous inner estuarine species). (3) Since
\end{abstract}


$1850 \mathrm{CE}$, the human impact progressively modified the general landscape of our study area with the construction of the Saint-Nazaire shipyard, the digging of the northern navigation channel and the polderization of the northern Bay. The southern channel was progressively abandoned by the main water flow in favor of the newly dug northern channel, causing the southern migration of the Bilho sandbank and the progressive filling of the southern channel.

\section{Highlights}

- Mid- to late Holocene infilling of the Loire incised valley $>$ Over the past $\sim 6$ kyrs BP, three main periods of hydro-sedimentary dynamics stand out Sea-level rise and regional climate control estuarine deposits - Anthropogenic impact becomes a main controlling factor after 1850 CE Sedimentological and foraminiferal proxies

Keywords : Macrotidal estuary, Mid-latitude estuary, Holocene paleoenvironment, Estuarine facies, Benthic foraminifera, Sea-level change 


\section{Introduction}

Estuaries are dynamic and sensitive physical and ecological systems that occur at the interface between terrestrial and marine environments. As such, they respond considerably to both natural climatic and geomorphologic changes, and to anthropogenic pressure; the latter started thousands of years ago (e.g., drainage and agriculture, grazing, saltpans), and increased in modern times (e.g., dredging, dyking up, damming, harbor management, heavy industries, urban settlement, intensive agriculture) (e.g. Colman et al., 2002; Borja et al., 2010; Moreno et al., 2014; Traini et al., 2015). Improving our knowledge of past environmental changes that influenced estuarine systems, whether triggered by natural internal processes (e.g., sediment supply, tidal regime, marine vs riverine influence), external forcing (e.g., solar irradiance, atmospheric circulation patterns) and/or by persistent human impact, is essential to understand recent and future regional environmental variability (Moreno et al., 2014; Kotilainen et al., 2014). Late Quaternary sediments deposited in estuaries have a good potential as archives for paleoenvironmental reconstructions. Estuaries tend to act as traps for both fluvial and marine sediments bearing expanded sedimentary successions and retaining both continental and marine environmental signals at high time resolution through high sedimentation rates (e.g., Colman et al., 2002; Leorri et al., 2006; Ghosh et al., 2009). Nevertheless, many problems arise from the reverse sides of these advantages because of the complexity of hydrosedimentary processes (e.g., transport, erosion, discontinuous sedimentation) making estuarine sediments poorly used for paleoenvironmental reconstructions in comparison with lacustrine and marine sediments. For instance, the mixed source of sediments from marine and continental origins makes their interpretation complex. This complexity is further found in the use of several sediment contents to trace back environmental changes, including most paleo-proxies (e.g., bio-indicators; Elliott and Quintino, 2007) or materials for chronological studies. For instance, radiocarbon dating of the sediments is difficult because of multiple sources of carbon in estuaries and reworking processes (Colman et al., 2002; Lougheed et al., 2013).

Sea-level changes strongly control the evolution of coastal environments during the late Quaternary (Clavé, 2001; Traini et al., 2013; McGowan and Baker, 2014). In particular, eustatic changes mainly control the accommodation space and therefore the morphology of estuarine systems (e.g. Jervey, 1988). In northwestern Europe, many modern estuaries, such as the Loire estuary, originate from the flooding and the filling of the Late Glacial Maximum (LGM) incised valleys during Holocene transgression (e.g. Dalrymple et al., 1994; Zaitlin, 
1994; Chaumillon et al., 2010; Proust et al., 2010). Several studies targeted the reconstruction of Holocene relative sea-level (RSL) along the French Channel and Atlantic coasts (e.g., Ters, 1973; Morzadec-Kerfourn, 1974; Ters, 1986; Van de Plassche, 1991; Lambeck, 1997; Leorri et al., 2012; Goslin et al., 2013; Stéphan and Goslin, 2014; Goslin et al., 2015). More recently, Goslin et al. (2015) compiled RSL data from the western Brittany and the southern UK coasts. In general, all these studies agree about three main phases characterizing Holocene transgression along the western French coast: 1) From $\sim 10 \mathrm{kyrs}$ BP to $\sim 6 \mathrm{kyrs}$ BP, sea level rose rapidly from $\sim-30 \mathrm{~m}$ to $\sim-4 \mathrm{~m}$, resulting in an increase in estuarine accommodation space and therefore an increase in sedimentation rates. In estuarine stratigraphical sequences, this phase is recorded as a transgressive system tract (TST) (e.g., Dalrymple et al., 1994; Zaitlin et al., 1994; Proust et al., 2010; Goslin et al., 2015); 2) From $\sim 6$ kyrs to $\sim 3$ kyrs, there was a pronounced slowdown in the rate of sea-level rise (Goslin et al., 2015), explained by a decrease in meltwater production from the global ice-sheets (Vink et al., 2007). This led to the reduction of estuarine accommodation space and the development of a part of European costal marshes and peatlands (Spencer et al., 1998; Allen, 2000; Clavé, 2001). This phase is recorded in estuarine sediment deposits as a high stand system tract (HST) (e.g., Dalrymple et al., 1994; Zaitlin et al., 1994; Proust et al., 2010; Goslin et al., 2015); 3) from 3 kyrs to present, sea-level rose slowly from $-2 \mathrm{~m}$ to the present RSL, reaching a near stabilization from 2 kyrs onwards (Ters, 1973; Stéphan and Goslin, 2014; Goslin et al., 2015). During this phase, the estuarine infilling was controlled by complex interactions between climate variability (e.g., Bond et al., 1997) and the consequent hydro-sedimentary dynamics, and more recently by human activity.

In estuarine systems, sediment characteristics and benthic foraminiferal assemblages are routinely used to reconstruct past environments in relation to Quaternary sea-level fluctuations (e.g., Scott and Medioli, 1980; Hayward et al., 1999; Fatela et al., 2009, Proust et al., 2010; Leorri et al., 2011; Delaine et al., 2014; Goslin et al., 2015). The succession of various estuarine sedimentary facies combined with the distribution of estuarine foraminiferal species reflect the morphodynamics of the system, water circulation patterns, river runoff and tidal dynamics, and the interplay between marine and freshwater inflow (e.g., Moreno et al., 2014). All of these processes are to be discussed as resulting from the mixture of natural internal forcing, regional climate, and human impact. However, for the same reasons as for the dating, interpretations drawn from sedimentary deposits and benthic foraminiferal faunas in estuaries remain somehow hampered by intrinsic processes such as transport and reworking. 
In this context, the Loire estuarine ecosystem has been poorly studied to date. As regards to Holocene hydrological, sedimentary and microfaunal variability, only a few studies attempted to answer this problematic via a multiproxy approach combining biological and sedimentary proxies (Ters et al., 1968; Visset and Barbaroux, 1972; Visset, 1973; Delaine et al., 2014). And yet, the Loire estuary, by being 1) one of the three major estuaries in France, 2) located at mid-latitude between two major atmospheric systems (Island low and Azores high) controlling the European Climate, and 3) under a macrotidal regime, is likely to be a sediment depot center able to record at high time resolution Holocene climate variability and sea-level fluctuations, and their impact on hydro-sedimentary and ecological processes.In this paper, we present a paleoenvironmental study from the lower inner Loire estuary near Saint-Nazaire (Fig. 1), including a detailed description of sedimentary facies successions of four sediment cores, and benthic foraminiferal content in one core located close to a mudflat. Our interpretations are supported by paleogegraphical reconstructions and historical data. Paleoenvironmental interpretations of benthic foraminiferal data are based on the results of two extensive programs describing the modern ecology of benthic foraminifera in the Loire estuary (SEMHABEL ${ }^{5}$ and $\mathrm{RS}^{2} \mathrm{E}^{6}$ projects). The main objectives of this work are: 1) to reconstruct the depositional history of the inner Loire estuary, and the response of benthic foraminifera to the mid- to late-Holocene marine flooding of the incised valley, and 2) to evaluate the consequent changes in estuarine morphological and hydro-sedimentary patterns.

\section{Study area}

\subsection{Hydrology and Geology}

The Loire is the longest river in France draining a catchment area of about $117480 \mathrm{~km}^{2}$; -and flowing into the Atlantic Ocean (northern Bay of Biscay). The Loire estuary covers an area of $\sim 217 \mathrm{~km}^{2}$ and extends for $\sim 80 \mathrm{~km}$ long (Ciffroy et al., 2003). At the gauging station of SaintNazaire, the annual flow of the Loire River is on average $900 \mathrm{~m}^{3} / \mathrm{s}$, fluctuating between low water periods during summer and autumn $\left(250 \mathrm{~m}^{3} / \mathrm{s}\right)$ and flood periods during winter $(>1800$ $\mathrm{m}^{3} / \mathrm{s}$ ) (http://www.hydro.eaufrance.fr). At Saint-Nazaire, the maximum tidal range is $6.4 \mathrm{~m}$. In averaged conditions, the salinity front (upper limit of the mesohaline domain) is located upstream from Cordemais, $\sim 39 \mathrm{kms}$ from the river mouth (Fig. 1A). From Nantes to SaintNazaire, the Loire River flows through the crystalline rocks of the Armorican Massif. Its valley is constrained by two main geological structures: The Brittany belt (SE-NW) to the 
north and The Pays de Retz arching to the south (Fig. 1B). The valley widens gradually from Nantes to Saint-Nazaire forming a final bottleneck (Mindin / Saint Nazaire) which marks the limit of the inner estuary (Figs. 1A, B). The outer estuary is defined as the area between SaintNazaire-Mindin and Préfailles-Penchâteau headlands (Gallenne, 1974) (Fig. 1A). This specific morphology originates from 1) the successive Quaternary regressions leading to the incision of the Loire valley, and 2) the sedimentary infilling occurring mainly during the last transgression (Ottmann et al., 1968; Ters et al., 1968). The same architecture is observed for most northwestern European estuaries (e.g. Dalrymple et al., 1992, 1994; Zaitlin et al., 1994; Perillo, 1995).

\subsection{The Holocene sedimentary infilling}

Sediments deposited in the Loire estuary are sourced from both continental and marine origins:

Information about the continental signal is documented in the study of ArnaudFassetta et al. (2010). These authors investigated the main controls of the sedimentary infilling of the middle and lower Loire River during the Holocene, and described two main periods: 1) Before $\sim 4.5$ kyrs BP, the magnitude and frequency of floods were low in the middle Loire valley ( 400 km upstream from the Loire river mouth), and the resulting solid flux between watershed slopes and alluvial plains was reduced. The lower Loire valley ( 250 $\mathrm{km}$ upstream from the Loire river mouth) was drowned because of the rapid sea-level rise. This resulted in clayey peat deposition and the abandonment of the secondary channels. 2) From $~ 4.5$ kyrs BP to present, the fluvial activity increased, probably as a response to an external climatic control modifying the river profile slopes. In the lower Loire valley, sedimentation rates increased, peat bog disappeared, and abandoned channel were reactivated. From the Middle Age, early human activities impacted sedimentation all along the valley, leading to a progressive decreasing trend of the solid discharge (Milliman and Ren, 1995; Maillet et al., 2006)

Offshore the present day Loire River mouth, on the inner continental shelf, Proust et al. (2010) highlighted a dense network of paleovalleys using an extensive grid of highresolution seismic profiles. These authors identified two surimposed stratigraphical sequences from the two last glacial periods. The most recent (upper) sequence is composed, from base to top, of 1) the upper part of a Low Stand Tract (LST) consisting of meandering fluvial 
sediments, 2) estuarine low energy sediments (TST to HST) truncated by a wave ravinement erosion surface of Holocene age, and 3) offshore marine bioturbated muds.

The sedimentary infilling of the inner Loire estuary itself has received little interest to date. Above the substratum (composed of crystalline rocks of the Armorican Massif originating from the Hercynian orogeny), the infilling of the inner Loire estuary started during the LGM (Ters et al., 1968; Visset and Barbaroux, 1972; Visset, 1973; Barbaroux et al., 1974a; Barbaroux et al., 1980a), except for few lenses of Pliocene marine sediments and clayey sediments of Eemian interglacial age (Barbaroux et al., 1974a; Barbaroux et al., 1980b; see Fig. 1D). Holocene sedimentary infilling of our study area (Fig. 1D) attains a maximum thickness of $\sim 41 \mathrm{~m}$ at Mindin (Ters et al., 1968; Barbaroux et al., 1974a). The typical sedimentary sequence of the Loire valley infilling can be divided into two main parts as described by Barbaroux et al. (1974a; see Fig. 1D): 1) overlying the crystalline bedrock, the infilling sequence starts with a $5-10 \mathrm{~m}$ thick layer of coarse sediments deposited during the LGM, and composed of gravels, pebbly sands and glacial boulders (Ters et al., 1968; Barbaroux et al., 1974a, b). 2) The second layer, which forms the main part of the sedimentary infilling, is composed of Holocene alluvium. They are mainly composed of organic sediments and terrigenous sandy clays (Barbaroux et al., 1974a, b; Barbaroux et al., 1980a). Palynological studies allowed a rather precise dating of these deposits (Ters et al., 1968; Barbaroux, 1972 a, b; Visset and Barbaroux, 1972; Visset, 1973). Between 8.0 and 5.5 kyrs BP (Atlantic palynozone), the marine drowning of the paleovalley led to the deposit of brackish and open marine sediments with high sedimentation rate (Barbaroux, 1972a, b) (Fig. 1D). Between $\sim 5.5$ and $\sim 3.0 \mathrm{kyrs}$ BP (Subboreal palynozone), sediments reflect lagoonal conditions due to the slowing down of sea level rise. After $\sim 3.0$ kyrs BP (Subatlantic palynozone), sediments are mainly terrigenous due to increasing fluvial influence (Fig. 1D). 


\section{Material and Methods}

\subsection{Historical maps}

In order to illustrate the pre- and post-industrial paleogeographical evolution of the Loire estuary and therefore the morphological context of our paleo-records, eight historical maps of the study area from 1693 AD to 2008 AD were compiled from different sources (Table 1). Apart from the imprecise 1693 AD map, each map was georeferenced (WGS84 geodesic system) with ArcGIS10® software using remarkable geographic points (rocky outcrops, historical buildings like churches, etc). Using the GIMP 2.0 software, these maps (for which altitudes are relative to zero $\mathrm{CM}^{7} 6^{7}=$ Lowest Low Tide Level (LLTL)) were simplified into four bathymetric ranges with a standardized chart: supratidal domain (above Highest High Tide Level (HHTL)), intertidal domain (between HHTL and LLTL), subtidal domain (below LLTL until $5 \mathrm{~m}$ depth) and deeper than $5 \mathrm{~m}$ LLTL (Fig. 2).

\subsection{Core sampling}

Four sediment cores (SC03, SC05, SC14, and SC17) (9 cm diameter, 5.06-5.73 m length) were collected in the lower inner estuary near Saint-Nazaire (Table 2; Figs. 1 and 3 ). Under the supervision of Nantes-Saint-Nazaire seaport $\left(\mathrm{GPMNSN}^{4}\right)$, the company FUGRO Géotechnique was in charge of the sampling using a vibrocorer onboard the multicat type workboat «Willendeavour» (Williams shipping, Southampton). Cores SC03, SC05, and SC14 are located on the right bank of the present day navigation channel whereas core SC17 is located on the left bank of the channel, near the Bilho bank (Fig. 1C). Each core was sliced into $1 \mathrm{~m}$ long sections (Fig. 3). On each core, 2 half-sections $(50-100 \mathrm{~cm}$, and 250-300 cm) were used by the GPMNSN ${ }^{4}$ for routine geochemical monitoring and are no more available for this study (Fig. 3). Core geographic coordinates were first issued by the GPMNSN ${ }^{4}$ under the Lambert II projection system and were subsequently converted into the WGS84 geodesic system (Table 2). 


\subsection{Radiocarbon dating and sedimentological analyses}

Radiocarbon dating (12 AMS ${ }^{14} \mathrm{C}$ dates in total) was performed by the Poznan Radiocarbon Laboratory (Poland) using a minimum amount of $1.0 \mathrm{mg}$ of pure carbon. Depending on the availability of suitable dating material, dating was performed on bivalve shells, plant debris, or bulk organic carbon (TOC: Total Organic Carbon) in muddy layers (Table 3). Absolute AMS ${ }^{14} \mathrm{C}$ ages were then calibrated (converted to calendar ages: cal. yrs BP) using the IntCal13 radiocarbon calibration curve (Reimer et al., 2013). The calibration was performed using the program CALIB 7.1 (Stuiver and Reimer, 1993). For post-nuclear testing sample Poz-74595 (SC05; 123-124cm), the calibration was performed with NHZ1 bomb curve extension (Hua et al., 2013) of IntCal13 using the program CALIBomb (Reimer et al., 2004). Calibrated ages indicate values with 2 standard deviations ( $\sigma \sigma ; 95 \%$ of confidence). No reservoir age corrections were applied because of the absence of accurate reference data in the study area.

Using visual observation and high-resolution photos obtained in IFREMER $^{8}$ (Brest) (Fig. 3; see HD photos in supplementary material), sedimentological analysis consisted of detailed and rigorous lithological visual description of the four studied cores in terms of lithology, sedimentary structures, bioturbation features, etc. As a result, eight characteristic estuarine facies were distinguished (Fig. 4), described and interpreted following the commonly used sedimentological reference works (e.g., Reineck and Singh, 1973; Davis and Dalrymple, 2012) and studies with emphasis on estuarine environments (e.g., Tessier, 1993; Fenies and Tastet, 1998).

\subsection{Foraminiferal analyses}

Because of the generally fine-grained sedimentation which likely reflects a continuous record, core SC05, located on the edge of the Méan mudflat (Fig. 1C), was selected for investigating its foraminiferal content. Benthic foraminiferal fauna was analyzed in 67 samples $(1 \mathrm{~cm}$ thick) (Fig. 6; Appendix 1). Samples were wet-weighed, dried and re-weighed to obtain the final dry weight. All subsamples were then washed through $150 \mu \mathrm{m}$ and $63 \mu \mathrm{m}$ sieves. In this study, we focused on the $>150 \mu \mathrm{m}$ fraction. Interpretation of foraminiferal assemblages was based mainly on the modern ecology of benthic foraminifera in the Loire estuary resulting from the SEMHABEL $^{5}$ project (Mojtahid et al., 2016). Taxonomic references used to determine 
benthic foraminifera at a species level are cited in Appendix 2. All foraminiferal counts were converted to relative abundances. A statistical threshold of 10 counted individuals was established. Samples with less than 10 counted individuals were discarded from the data matrix for relative abundance calculations, and statistical analysis. Although we are aware that the counting error increases considereably with a threshold of 10 individuals (Fatela and Taborda, 2002), in such estuarine environments only very few species are dominant (Murray, 2006). In order to better describe spatial patterns of faunal variability, we applied a Principal Component Analysis using PAST (PAleontological Statistics, 3.08, Hammer et al., 2001). Only taxa occurring with more than $5 \%$ in at least one sample were retained in the PCA analysis. Input for the PCA consisted of all species relative abundances and sample depths in core SC05. Census data are presented in Appendix 1.

\section{Results and interpretations}

\subsection{Historical context}

The 1693 AD, and 1850 AD maps show a similar morphology. A large bay (Montoir Bay) was present on the northern part of the lower inner estuary partly isolated by a tidal bank (Bilho) from the main flow channel (Fig. 2). The confluence of the Brivet River cut through a tidal mudflat (the Méan mudflat) which is clearly highlighted by the HHTL - LLTL limits drawn on the $1850 \mathrm{AD}$ map. In $1693 \mathrm{AD}$, no human constructions were present whereas in $1850 \mathrm{AD}$ a $\sim 250 \mathrm{~m}$ long dock was built as the premise of the future Saint-Nazaire shipyard (Fig. 1C).

In $1902 \mathrm{AD}$, the Saint-Nazaire dock was extended to nearly its present size (almost $4 \mathrm{~km}$ long). By being more precisely mapped, the 1902 AD map, shows the depth of both northern and southern channels. The main river flow was channeled south of the Bilho bank (Fig. 2).

The Montoir Bay was artificially isolated from the estuary for industrial purposes. That is first visible on the 1938 AD map. The polderization of the Montoir Bay was entirely completed before $1984 \mathrm{AD}$. 
A new channel dedicated to navigation was dug along the right estuary bank between 1938 AD and 1948 AD. Between 1948 AD and 2008 AD, the northern main channel deepened whereas the southern channel retracted until being nearly closed upstream. Sediments issued from the digging were deposited on the Bilho bank between 1979 and 1981 AD $\left(\sim 7.510^{6} \mathrm{~m}^{3}\right.$; GPMNSN $^{4}$ ). The deepening of the northern channel led to an increase in the water flow north of the Bilho bank and consequently a decrease in the southern channel. This favoured the filling of the southern channel. The southern channel is now almost filled, and the area is composed mainly of intertidal mudflats (Fig. 2).

\subsection{Sedimentological characteristics}

\subsubsection{Facies description}

The observation of high definition core photos presented in Figure 3 permitted the distinction of eight sedimentary facies (Fig. 4). Nine core segments (14 cm long) (white rectangles in Fig. 3) were selected to highlight these facies in Figure 4. In Figure 4A, the facies are ordered following a generally decreasing grain size. Hereafter, we describe in detail each facies and we give a brief interpretation in terms of estuarine deposit environments based on the commonly used literature (e.g., Reineck and Singh, 1973; Tessier, 1993; Fenies and Tastet, 1998; Davis and Dalrymple, 2012):

Facies $\mathbf{A}\left(\boldsymbol{F}_{\boldsymbol{A}}\right)$ (Figs. 3; 4A): This facies is only present in the lowermost $5 \mathrm{~cm}$ of core SC03 ( $<1 \%$ of the studied cores). It consists of clast-supported monogenic (gneiss) angular clasts (2 - $3 \mathrm{~cm}$ large), in a clayey, medium to coarse-grained sand matrix. The sand fraction is dominated by angular quartz grains and gneiss debris. We can observe traces of cirripeds on the rock debris.

Interpretation- Pebbles and sands present the same composition as the near surface crystalline bedrock (metamorphic gneiss injected by numerous quartz veins) that outcrops on the right bank of the Loire estuary and particularly nearby core SCO3 (e.g. Barbaroux et al., 1974a) (Fig. 8B and C). The nature (gneiss) and shape (angular) of these rock clasts indicate that $F_{A}$ is most likely the product of bedrock weathering. Traces of cirripeds indicate that the crystalline elements were accumulated in the intertidal zone. Sediment composing Facies A can be interpreted as an erosion product of a local crystalline substratum. 
Facies B $\left(\boldsymbol{F}_{\boldsymbol{B}}\right)$ (Figs. 3; 4A): This facies is observed in a $5 \mathrm{~cm}$ thick layer only in core SC03 ( $<1 \%$ of the studied cores). $F_{B}$ is composed of polygenic and very poorly sorted clastsupported conglomerate (from coarse sands to pebbles: $>1 \mathrm{~mm}$ to $4 \mathrm{~cm}$ ). The nature of pebbles and gravels is diversified with quartz, gneiss and other metamorphic rocks. Pebbles are flat and well-rounded, some of which carry traces of cirripeds on all sides. Sands are composed of subangular to subrounded quartz, feldspars, plagioclase, pyroxene, and rock debris. Shell debris (Mytilus edulis), also colonized by cirripeds, are present. Only $5 \mathrm{~cm}$ of this facies is observed because of its position above the missing sedimentary section.

Interpretation- The polygenic nature, size and shape (flat to well-rounded) of the pebbles indicate different sediment sources, and deposition in a high energy (marine) environment.

Facies $\mathbf{C}\left(\boldsymbol{F}_{\boldsymbol{C}}\right)$ (Figs. 3; 4A): This facies is observed in 2 to $27 \mathrm{~cm}$-thick layers $(\sim 8 \%$ of the studied cores). It is characterized by clay pebbles, ranging in size from 0.1 to $4.0 \mathrm{~cm}$, that float isolated in poorly-sorted, coarse to medium-grained sands. The sand fraction, comprising sub-angular to sub-rounded quartz with some magnetite grains, is organized in thin laminae underlined by the coarsest sand grains. No traces of living organisms or bioturbation are observed. The base of $F_{C}$ is a sharp and erosive contact.

Interpretation- Clay pebbles derive from strong currents eroding either a channel bank or subaerial muddy flat deposits, as those found on intertidal muddy estuarine banks. Clay pebbles floating in azoic unsorted coarse sand reflect high-energy depositional processes with high sedimentation rate. The sharp basal erosive surface indicates an abrupt increase in energy. This Facies $\mathrm{C}$ is usually found in channel axes. The absence of traces of living organisms or bioturbation suggests a strong fluvial influence on sediment transport.

Facies D $\left(\boldsymbol{F}_{\boldsymbol{D}}\right)$ (Figs. 3; 4A): This facies is observed in 1 to $5 \mathrm{~cm}$-thick layers, only in core SC05 ( 1\% of the studied sections). It is fining upwards from very coarse to coarse sands. These sands are dominated by sub-angular to poorly rounded quartz with minor magnetite grains. Bivalve shell fragments $(0.1$ to $3 \mathrm{~cm})$ are abundant but no bioturbation is observed. This facies shows a sharp basal erosive surface. 
Interpretation- The coarse grains with shell fragments, present as 1 to $5 \mathrm{~cm}$-thick layers lying on a sharp erosive contact, indicate short high-energy events. The mixed angular and rounded quartz grains are probably sourced from a large reworking surface. The absence of bioturbation might indicate a high accumulation rate. The fining-upward sequence with a basal erosive surface indicates a slowing down of the energy after a violent discharge. $F_{D}$ reflects high-energy, sudden deposits as found in coastal storm washovers.

Facies $\mathbf{E}\left(\boldsymbol{F}_{\boldsymbol{E}}\right)$ (Figs. 3; 4A): This facies is observed in the lower two meters of core SC17 ( $\sim 10 \%$ of the studied sediments). It is characterized by poorly sorted, medium to very coarse sands. Similarly to $F_{C}$ and $F_{D}$, the sand fraction comprises sub-angular to poorly rounded quartz with magnetite grains. Sands are organized in cross-bed sets, all oriented in the same direction. Layers of sand ( $\sim 5 \mathrm{~cm}$ thick) are coarsening upwards, and are interbedded with clayey silts or organic-rich clays $(<1 \mathrm{~cm}$ thick).

Interpretation- The cross-bedding structure indicates small ripples (few centimeters high) accumulating under a fluctuating moderate-energy (unidirectional) flow interrupted by calm periods allowing decantation of mud draps. Therefore Facies E, which is mostly composed of sands (Fig. 3), points to a tide-influenced environment which can be interpreted as a tidal sand bar (Fenies and Tastet, 1998).

Facies $\mathbf{F}\left(\boldsymbol{F}_{\boldsymbol{F}}\right)$ (Figs. 3; 4A): This facies is observed in 10 to $200 \mathrm{~cm}$-thick layers only in core SC03 (>20\% of the studied sections). It is composed of bluish gray fine to medium sands with muddy flaser structures. The sand fraction is dominated by angular quartz grains and micas. Shell fragments $(0.1$ to $1.0 \mathrm{~cm})$ are abundant whereas plant debris are only present with low numbers. Centimetric sand layers are underlain by sharp erosive surfaces.

Interpretation- Sand grain size indicates a moderate-energy depositional environment. The flaser structures indicate low energy periods that are intercut by frequent bursts of energy as shown by the interbedded erosional surfaces. These alternations are typical of tidal dynamics, e.g. powerful tidal currents alternating with slack waters. Facies F can be interpreted as moderate-energy tidal channel deposits accumulating in secondary network drainage of a tidal flat, located aside the axial and main branch of the channel network. 
Facies $\mathbf{G}\left(\boldsymbol{F}_{\boldsymbol{G}}\right)$ (Figs. 3; 4A): This facies is observed in 5 to $150 \mathrm{~cm}$-thick layers $(\sim 30 \%$ of the studied sediments). It is characterized by an alternation of millimetric to centimetric layers of well-sorted silts to fine sands with clayey interbeds (Fig. 4B). The silty-sand fraction is dominated by angular to subangular quartz grains and micas with some sponge spicules and bivalve shell fragments. The silty and clayey fine layers seem to be organized into doublet or triplet beddings within a typical centimetric to decimetric sedimentary sequence: the silty layers thicken up $(0.1 \mathrm{~cm}$ to $1 \mathrm{~cm})$ from planar-, to lenticular-, then wavy-, and finally flaserbedding and then decreases in thickness progressively. Large parts of the sequences are truncated by frequent erosion surfaces. Bioturbation is common (burrows) (Fig. 4B).

Interpretation- Tessier (1993) interpreted these silty-clayey alternations as issued from daily tidal currents, with silts being deposited during the flood or ebb, and clays during the slack stage. This $\sim 10 \mathrm{~cm}$ sequence from horizontal to flaser bedding and reversely deposited in a low sedimentation rate environment might indicate a tidal cyclicity at a longer time-scale than neap-spring cycle described by Tessier (1993) (e.g., equinoctial tides, saros cycle).

Facies $\mathbf{H}\left(\boldsymbol{F}_{\boldsymbol{H}}\right)$ (Figs. 3; 4A; 4B): This facies is observed in 2 to $140 \mathrm{~cm}$-thick layers ( 40\% of the studied sediments). It is characterized by bluish gray silty clays containing rare millimetric silty to fine sandy laminae (linsen structures). The silty-sand fraction is dominated by micas and plant debris. Parts of this facies that are very rich in organic material present a "lumpy" aspect (See Fig. 3, core SC05-450-500 cm). Shells are rare but very often with shell doublets (Scrobicularia plana), and are concentrated in some parts in layers of 1 to $2 \mathrm{~cm}$ thick. Bioturbation consists of small millimetric burrows, filled with silt. The basal contact is net when the underlying facies is sandy $\left(F_{B}, F_{C}\right.$, and $\left.F_{D}\right)$.

Interpretation- The dominance of clay deposits and the disappearance of sandy layers (except in the rare linsens) are indicative of lower energy environment than the previous facies, still under tidal influence. The shell layers may result from storm overwash.

\subsubsection{Sedimentary columns}

Based on the eight sedimentary facies described previously (Figs. 3 and 4), we propose hereafter a simplified lecture of the sedimentary columns of the four studied cores (Fig. 5) following a stratigraphic order from the deepest to the shallowest core: 1) Core SC14 (-17.8 to $-12.7 \mathrm{~m} \mathrm{LLTL})$ is generally fine-grained dominated by facies $F_{G}$ and $F_{H}$, i.e. tidal facies, 
except for sections $300-430 \mathrm{~cm}$ and $30-50 \mathrm{~cm}$ which are coarse-grained dominated by $F c$, i.e. flood deposits. 2) Core SC17 (-15.2 to -9.5 m LLTL) is generally coarse-grained (facies $F_{E}$, i.e. tidal bar facies) in the first half and more fine-grained in the top half ( $F_{G}$ and $F_{H}$, i.e. intertidal mudflat facies); the latter being interrupted by several coarse deposits (Facies $F_{C}$, i.e. flood deposits). 3) Core SC05 (-9.6 to- 3.9 m LLTL) is mostly fine-grained with a dominance of facies $F_{H}$, i.e. tidal facies, occasionally interrupted by thin coarse-grained layers corresponding to $F_{D}$, i.e. storm washovers. 4) Core SC03 ( -9.1 to $-3.4 \mathrm{~m}$ LLTL) is mostly composed of medium sands within the facies $F_{G}$ and $F_{F}$, i.e. low tidal flat and secondary drainage facies. The base of core $\mathrm{SC03}$ is characterized by the pebbly facies $F_{A}$, i.e. substratum weathering facies.

\subsection{Benthic foraminiferal content of core $\mathrm{SC} 05$}

Foraminiferal analyses were conducted only on core SC05 because of the overall fine-grained sedimentation. The number of sorted specimens in each sediment layer varies from 0 to 321 (Fig. 6; Appendix 1).

The most dominant benthic foraminiferal species are: Ammonia tepida (14.9\% on average including all samples), Lobatula lobatula (14.4\%), Haynesina germanica (12.5\%), Cribroelphidium excavatum (11.8\%), Planorbulina mediterranensis (10.0\%), and Elphidium excavatum subsp. Clavatum (7.3\%) (Fig. 6; Plate 1).

Other species are present with $>5 \%$ in at least one sample: the miliolids (Adelosina sp., Edentostomina sp., Quinqueloculina spp. and Miliolinella subrotunda) (3.2\%), Elphidium williamsoni (2.7\%), Ammonia parkinsoniana (2.7\%), Ammonia beccarii (2.4\%), Lagena spp. (2.1\%), Asterigerinata mamilla (2.0\%), Elphidium aculeatum (1.2\%), Elphidium decipiens (1.2\%), the deep-water agglutinants (Textularia spp. and Remaneica plicata) (1.1 $\%)$, Gavelinopsis praegeri (1.1\%), Homalohedra williamsoni (1.0\%), Elphidium granosum $(0.7 \%)$, the marsh agglutinants (Ammoglobigerina globigeriniformis, Trochammina inflata and Jadammina macrescens) (0.7\%), Favulina melo (0.4\%), Procerolagena clavata (0.4\%), and Globobulimina sp. (0.1\%) (Fig. 6; Plate 1; Appendices 1 and 2). 
A Principal Component Analysis (PCA) was performed on the basis of the percentage data of all taxa occurring with more than $5 \%$ in at least one sample. The results of this PCA are presented in Figure 7. Axes 1 and 2 account respectively for $37.09 \%$ and $20.92 \%$, and together they explain $58 \%$ of the total variance of the dataset. The PCA separates the faunal assemblages into three main species groups with rather similar ecological requirements (Fig. 7):

Group 1 (G1) is mainly dominated by A. tepida and H. germanica. The other subsidiary species E. decipiens, E. granosum, and E. williamsoni do not have a significant weight.

Interpretation- Ammonia tepida and H. germanica live, at present, in the intertidal mudflats and the upper subtidal fine-grained domains of the lower inner estuary (e.g., The Méan mudflat located very closely to SC05) (Thibault de Chanvalon et al., 2015; Mojtahid et al., 2016).

Group 2 (G2) is mainly dominated by C. excavatum, E. excavatum subsp. clavatum and $P$. mediterranensis. The other subsidiary species G. praegeri, Lagena spp., H. williamsoni, and marsh agglutinants do not have a significant weight.

Interpretation- Cribroelphidium excavatum and E. excavatum subsp. clavatum inhabit the sandy subtidal sediments of the lower inner and outer Loire estuary (Mojtahid et al., 2016). By being associated with P. mediterranensis, a stenohaline epifaunal species (Murray, 2006), Group G2 rather indicates the external limit of the outer estuary, i.e. the river mouth.

Group 3 (G3) is mainly dominated by L. lobatula, A. beccarii, A. parkinsonian and miliolids. The other species A. mammilla, E. aculeatum, Globobulimina sp., deep agglutinants, $H$. clavatum, and F. melo do not have a significant weight.

Interpretation- Lobatula lobatula, A. beccarii, A. parkinsoniana, and miliolids are stenohaline species known to inhabit shallow environments from the upper continental shelf (e.g., Murray, 2006; Camacho et al., 2015). 
Group G1 is present all along the record but dominates the upper $50 \mathrm{~cm}$ (50-57\%) (Fig. 6; Appendix 1). Group G2 is dominant (42-77\%) between $\sim 573$ and $301 \mathrm{~cm}$ sediment depth, except at depths $572 \mathrm{~cm}, 445 \mathrm{~cm}$, and $407 \mathrm{~cm}$ where group G1 is dominant with $40 \%, 47 \%$ and $52 \%$ respectively. The highest densities are found in this section. Between $\sim 251$ and 100 cm sediment depths, Group G3 is generally dominant (30-83\%). All species forming group G3 do not vary in the same way. For instance, Lobatula lobatula (40\%) is highly dominant at $229.5 \mathrm{~cm}$ sediment depth (at this depth, G1 is totally absent), whereas Ammonia parkinsoniana dominates at $194.5 \mathrm{~cm}$ depth (Only C. excavatum from G2 is present with > 5\%). Group G3 accounts for 23-36\% in the upper $50 \mathrm{~cm}$ of core SC05 (Fig. 6; Appendix 1).

\section{Discussion}

\subsection{Limitations of the study}

\subsubsection{Radiocarbon dating}

In estuaries, radiocarbon dating of sediments is difficult because of multiple factors linked mostly to estuarine hydrodynamics (Colman et al., 2002 ; Lougheed et al., 2013). In our case study, inversions and inaccuracies in ${ }^{14} \mathrm{C}$ dates can be explained by:

a- The discontinuous sedimentary patternis characterized by the presence of erosive surfaces, hiatuses, high sedimentation rates, reworking and transport processes. This pattern is characteristic of every estuarine system (e.g., Colman et al., 2002; Angulo et al., 2008). This can explain partly the observed ${ }^{14} \mathrm{C}$ dating inversions, either between samples from different nature or within samples from the same nature (Table 3; Fig. 5).

b- The scarcity of adequate and continuous dating material (e.g., foraminiferal shells), left us with no choice but to date material of different nature. The dating of diverse samples includes, in our study, heterogeneous terrestrial remains (plant debris), estuarine mollusk shells (Scrobicularia plana) and bulk organic carbon in mud (complex mixture of terrestrial (e.g., shoreline erosion sediment, riverborn suspended sediment) and marine remains (e.g., organic matter produced by microphytobenthos) (Table 3). In our samples, most inversions are related to older ages from plant debris and bulk organic carbon compared with the younger ages from bivalve shells (Fig. 5). This feature is commonly found in most estuarine sediments dated on samples from different nature (e.g., Angulo et al., 2008; de Souza et al., 2012) and is 
explained by the fact that plant debris and organic matter, as the abraded wooden fragments, are most likely transported and that the terrestrial organisms' times of death were older than the times of deposition. Since most plant debris are found in core SC14 (containing the oldest sediments), plant remains could have been transported from the near continent to the study area when the sea level rise was slowing down and where the riverine influence starting to increase around 5.0-4.0 kyrs BP as described by Ters et al. (1968), Visset and Barbaroux (1972) and Visset (1973) (see section 2: study area). On the other hand, potential problems for ${ }^{14} \mathrm{C}$ dating on molluscs include transportation and redeposition, burrowing, and reservoir effects from the water in which the shells formed. For example, the bivalve Scrobicularia plana (analysed in core SC05) is an endobenthic deposit-feeder digging burrows of 10 to 20 cm deep (Bouchet et al. 2009, Soares and Sobral 2009), which means that it can record ages younger than the sediment layer where it is found. In general, biogenic carbonates (in our case, mollusks) appear to provide the most reliable material for ${ }^{14} \mathrm{C}$ dating except from transport and reworking effects. In cores SC05 and SC03, the dated bivalves at $351 \mathrm{~cm}$ and $538 \mathrm{~cm}$ respectively, were found in a coarse sandy matrix (See HD photos in supplementary material) probably indicating transportation and reworking. Unfortunately, the presence of these fossilizing organisms was scarce in our samples which led us to use other "less" reliable material such as plant debris and bulk organic carbon to date our sediments. Following Angulo et al. (2008), the ${ }^{14} \mathrm{C}$ ages provided by plant debris with long transport can be of hundreds to thousands of years older than depositional time.

For those reasons, we decided not to present an age model for this study and only use the obtained ${ }^{14} \mathrm{C}$ dates to give a general chronological framework for our sedimentary archives. This also invited us to be very precautionous that our interpretations (see paragraph 5.2.) do not exceed this temporal limitation and remain correct with a possible time error of a thousand years (especially for TOC and plant debris). Also we chose not to correct our ages for an eventual reservoir effect. In estuaries, the error in reservoir effect estimation can be of great importance. For instance, the inorganic carbon in waters used by calcifying organisms may be contaminated by ancient carbon issued from the dissolution of carbonate or crystalline rocks (e.g., Colman et al., 1990; Rea and Colman, 1995; Philippsen, 2013). 
Keeping in mind all the factors that may bias ${ }^{14} \mathrm{C}$ ages in our samples, it is interesting to note that when comparing ${ }^{14} \mathrm{C}$ ages obtained from material of the same nature, the chronological suite is generally well respected (Table 3; Fig. 5). The only exception can be found in the similar ${ }^{14} \mathrm{C}$-plant debris ages found in two different layers from core SC14 $(241.5 \mathrm{~cm}$ and 374 $\mathrm{cm}$; Table 2) indicating perhaps a very high sedimentation rate at the time. Therefore, the four sedimentary cores cover a maximum period of $\sim 6.5$ cal. kyrs BP, with core SC14 recording a period between $\sim 6.5$ and $\sim 4.2$ cal. kyrs BP, core SC17 a period between $\sim 5.4$ and $\sim 4.0$ cal. kyrs BP, core SC05 a period between $\sim 4.0$ cal. kyrs BP and the present day, and SC03 a period between $\sim 0.7$ cal. kyrs BP and the present day.

\subsubsection{Benthic foraminiferal analyses}

With values ranging between 0 and 321 sorted specimens, benthic foraminiferal densities found downcore SC05 are low compared to what is found in similar estuarine sedimentary archives (e.g. Ghosh et al., 2009; Melis and Covelli, 2013; Moreno et al., 2014). Two main factors may explain the scarce presence of benthic foraminifera in our sediments:

- Core SC05 is characterized by an overall fine homogeneous sedimentation (Fig. 5) indicating a calm depositional environment rich in organic matter. This is infered from the generally dark color indicative of reducing conditions during deposition (see HD photos; supplementary material). An important input of organic material usually results in intense microbial activity for its recycling, and hence a high consumption of dissolved oxygen in the water column (Talke et al., 2009). For many foraminiferal species, there is an optimum range of organic inputs and oxygen content in which they reproduce, are competitive, and attain their maximum abundance (Altenbach et al., 1999; Gooday et al., 2000; Jorissen et al., 2007; Caulle et al., 2014). Although some species of benthic foraminifera are able to survive complete anoxia (Piña-Ochoa et al., 2010), it appears that oxygen becomes a limiting factor for foraminiferal survival below $45 \mu \mathrm{M}$ (e.g., Sen Gupta and Machain-Castillo, 1993; Gooday, 1994; Jorissen et al., 1995). However, several of the common species (e.g., Ammonia tepida, Haynesina germanica) found in core SC05 survive dysoxia/anoxia (Moodley and Hess, 1992; Thibault de Chanvalon et al., 2015; Mojtahid et al., 2016). It is therefore unlikely that depleted oxygen concentrations are responsible for the scarce presence of foraminifera in our samples. 
- It is more probable that our paleoecological record suffered from taphonomic processes. In macrotidal environments (e.g., the Loire estuary), transport due to tidal action in addition to that caused by waves and wave-induced currents can be significant processes in introducing allochtonous species (Murray and Hawkins, 1976; Brasier, 1981; Murray and Alve, 1999; Wang, and Chappell, 2001). This is manifested in our samples through: 1) the presence of allochtonous stenohaline species (e.g., L. lobatula, P. mediterranensis, G. praegeri) (Fig. 6), although this presence in the oldest samples may also mean a different paleoenvironment, and 2) through etching and break of test walls (Plate 1). The latter can also be the signs of decalcification due to dissolution of calcareous tests. On the other hand, it has commonly been observed that calcareous foraminifera are poorly preserved in marsh sediments (e.g., De Rijk and Troelstra, 1999; Murray and Alve, 1999). Carbonate dissolution is common in marsh and mudflat settings throughout the world and may be caused by corrosive bottom or pore waters as resulting from the metabolization of organic matter (Reaves, 1986). Even in subtidal sediments, severe dissolution of calcareous foraminifera has been reported where the irrigated burrows and tubes of the macrofauna prevented the build-up of carbonate alkalinity (Green et al., 1993). In the probability of a transport, tests of allochtonous species must have been brought to the study site in suspension, and/or attached to marine algae since sediments of core SC05 are homogeneous and fine-grained (Wang and Chappell, 2001).

Even if our paleoecological record must have suffered from relatively important taphonomic loss, a rather logical ecological pattern stands out from the foraminiferal succession through time (Fig. 7; see paragraph 5.2).

\subsection{Reconstruction of the inner Loire estuarine environment from mid-to late-Holocene}

River discharge, tidal processes and oceanic swell or wind wave incursions are the main hydrodynamic factors that control sediment distribution and shape (e.g., channel network patterns and shifts, sand banks, river bank accretions) of estuaries (Boyd et al., 1992; Dalrymple et al., 1992, Schröder-Adams, 2006; Traini et al., 2013). On a long time scale, these estuarine characteristics are controlled by sea level variations and are mainly influenced by the regional climate regime. Anthropogenic factors affect only the most recent deposits. Following our sedimentary and microfaunal analyses, the four studied cores were positioned within their approximate chronostratigraphic frameworks (chap 5.1) and will be interpreted in the following in terms of paleogeography (Fig. 8). The superposition of the different facies 
follows a rather logical sedimentary succession (Fig. 5). This sedimentary succession has been formed during three main phases, from the mid-Holocene to the present:

A- The period from $\sim 6.0$ kyrs to $2.5 \mathrm{kyrs}$ is recorded in cores SC14 and SC17 and the lower part of core SC05 (Fig. 5). In core SC14, sediments posterior to $\sim 4.0 \mathrm{kyrs}$ are lacking (Fig. 5) because the core is located within the present navigation channel that was dug at the beginning of the $20^{\text {th }}$ century and was regularly dredged since then (Mougani, 1982; Mignot, 1993; http://www.nantes.port.fr/). Since the top core of SC17 is not dated, and since this area was also dredged to enlarge the channel (Mougani, 1982; Mignot, 1993; http://www.nantes.port.fr/), the most recent sediments are also most likely lacking. We can estimate the age of the SC17 top core at about 4.0 kyrs BP by corresponding the upper coarsegrained sediments of core SC17 to the upper coarse-grained sediments of core SC14 (Fig. 5). This age is coherent with the bottom of core SC05, dated at $\sim 3.9 \mathrm{kyrs}$ BP and present at the same elevation (LLTL) (Fig. 5). To better visualize the landscape during the $\sim 6.0-2.5 \mathrm{kyrs}$ time period, we used the outer limits of the Holocene alluvium fluviomarine deposits from Paimboeuf and Saint-Nazaire geological maps (1/50000; $\left.\mathrm{BRGM}^{10}\right)$ as indicative of the maximum flooding surface (Fig. 8A). Hereafter, we discuss this vertical succession chronologically and as related to natural forcing factors:

The time period from $\sim 6.0$ to 2.5 kyrs BP corresponds to a period of slowing down of sealevel rise until attaining a maximum around 2.5 kyrs (Ters et al., 1968; Goslin et al., 2015) (= the maximum of the Flandrian transgression; Ottman et al., 1968 and Ters et al., 1968). At the time, the landscape was probably similar than that shown in figure $8 \mathrm{~A}$ for the maximum of the Flandrian transgression. During the maximum flooding, the Brivet River and Montoir Bay were not part of the general landscape (Fig. 8A). Instead, a large brackish bay extended over and around the study area with two connections to the sea: a main entrance located at the present river mouth and a secondary outlet between Piriac-sur-Mer and Pointe du Bile (Fig. 8A). The Holocene infilling of this large brackish bay (between the study area and Piriac-surMer) was estimated at about 15-25 m thick (http://infoterre.brgm.fr).

The presence of fine-grained tidal rythmites $\left(F_{G}\right.$ and $\left.F_{H}\right)$ in core SC14 (which is located at present in the main channel) indicates calm hydrodynamic conditions. This deposit was possible in the southern part of the large brackish bay isolated from the main water flow axis by the Bilho bank (Fig. 8A). The main natural channel for riverine flow might have been located along the southern part of the estuary as it is shown on the 1693 AD map (Fig. 8A). 
Therefore, core SC14 records the infilling of a calm lateral bay in the drowned Loire valley with some riverine flood events (as indicated by the intermittent presence of $F_{C}$ ) from $\sim 6.5$ to 4.2 kyrs BP.

From $\sim 5.4$ to $\sim 4.0 \mathrm{kyrs}$, sediments of core SC17 (which is situated on the northern flank of the modern Bilho sandbank; Fig. 1) indicate a more dynamic environment than at core SC14 site (Fig. 5). The facies succession, from generally coarse-grained cross-bedded sands to neap-spring sequences, is typical of a tidal bar accretion followed by a period of stabilization as an intertidal mudflat (Figs. 5 and 8A). Core SC17 records a tidal environment linked to the main channel activity with periods of sand bank progradation resulting from high riverine sediment supply (Fig. 8A). The presence of several thick flood deposits (also present in core SC14) further indicates the prevalence of humid conditions. Delaine et al. (2014), who studied the Loire valley infilling near Nantes during the Holocene, report a period from 5.8 to 2.1 kyrs BP of high erosion regime and/or intense reworking denoting high hydrodynamics of the Loire River. Further upstream (near Orléans), Castanet et al. (2008) (referenced in ArnaudFassetta et al., 2010) highlighted two Holocene episodes of increased fluvial activity (high frequency and or magnitude of floods) between 6.8 and 3.5 kyrs BP.

B- The period from 2.5 kyrs BP to 1850 AD is recorded in cores SC05 and SC03 (Fig. 5). Since the Saint-Nazaire harbor, representing the first major human intervention affecting our study area, was created in the middle of the $19^{\text {th }}$ century (Decours, 2006), we consider that the 1850 AD map (the oldest georeferenced historical map available; Fig. 2) illustrates the natural landscape of the study area before any heavy human intervention (Fig. 8B). When comparing the $1693 \mathrm{AD}$ (non georeferenced) and the $1850 \mathrm{AD}$ maps, a relative stability of the landscape could be stated for at least 150 yrs (Fig. 2). At $\sim 2.5$ kyrs BP (the maximum of the Flandrian transgression), the sea-level stabilized at approximately its present value, and the French Atlantic coastline was similar to that of today (Ters, 1973). Since the complete infilling of the large drowned valley after the stabilization of sea level, we suppose that the landscape of our study area was similar to that shown in the 1693 and 1850 AD maps. Therefore, the stabilization of sea-level resulted in 1) the progressive infilling of the preexisting bay between the study area and the Piriac-sur-Mer - Pointe du Bile channel, 2) the channelization of the Loire estuary between Nantes and Saint-Nazaire, and the downstream migration of the river mouth, 3) the formation of the Montoir Bay between the two bottlenecks (Saint-Nazaire-Mindin and Donges-Paimboeuf), nearly closed to the east by the 
Bilho bank and its extension, and 4) the establishment of the Brivet River and the Méan mudflat in its mouth.

Both cores SC05 and SC03 have a similar bathymetrical range and a similar location on the edge of the present northern river-side near the navigation channel (Fig. 1). However, the different facies successions illustrate different sedimentary dynamics (Fig. 5):

Core SC05 records a generally homogenous sedimentation of silty muds rich in organic matter (Facies $F_{H}$; Fig. 4) with few short intervals of storm deposits rich in shell fragments (Facies $F_{D}$; Fig. 4). This sedimentation indicates a calm depositional environment controlled by tidal dynamics with occasional marine incursions during storm events. The natural presence of the Montoir Bay and the Bilho bank in the north indicates that the main water flow followed the southern channel (Fig. 8B). This configuration explains the homogeneous and fine nature of the sediments composing core SC05, present at the time in a sheltered location within the Montoir Bay with regards to the main flow channel. However, within this overall continuous and homogenous fined-grained sedimentation, foraminiferal assemblages show significant changes and describe three main periods (Fig. 6): a) from approximately 4.0 to 2.0 kyrs BP (taking into account only TOC ${ }^{14} \mathrm{C}$ ages, the more dominant and continuous dating material), the dominance of the species Group G2 primarily composed of C. excavatum and $P$. mediterranensis (typical of outer estuarine habitats) might indicate that the river mouth was situated at the time near our core location, which corresponds quite well to the paleogeographical configuration during the maximum of the Flandrian transgression attained around 2.5 kyrs BP (Fig. 8A); b) around 2.0 kyrs BP, species Group G3 composed of stenohaline species typical of shallow marine environments (L. lobatula, A. beccarii, A. parkinsoniana, and miliolids) increased in relative abundances. This indicates a transport from the adjacent upper Atlantic continental shelf. During this period, stabilization of sealevel led to the progressive sedimentary infilling of the large brackish bay that occupied our study area. The progressive shaping of the Loire estuary to its pre-industrial state (Fig. 8B) might have resulted in the channelization of the main entering currents and the resulting dynamics (amplification of tidal waves, easier incursion of storm waves). This probably intensified the transport in suspension and/or attached to marine algae of the allochtonous species of Group G3 to the study area. c) Around $0.5 \mathrm{kyrs}$ BP, the dominance of the autochthonous species of Group G1 (composed of the inner estuarine species A. tepida, and H. germanica) typical of the present day mudflat habitats (Mojtahid et al., 2016) might 
indicate the buildup of the Méan mudflat and the stabilization of the environment to its present day configuration.

On the other hand, core SC03 which is mostly formed by well sorted medium sands rich in quartz and millimetric shell debris (Facies $F_{F}$ and $F_{G}$; Fig. 5) (especially below $50 \mathrm{~cm}$; the upper $50 \mathrm{~cm}$ is more fine-grained - Facies $F_{H}$ ), is indicative of a dominance of marine influence from waves and tidal currents. Core SC03, unlike SC05, records the transition between marine and estuarine environments by being directly exposed to the main tide circulation and probably storm wave entrance into the inner estuary.

C- Since $1850 \mathrm{AD}$, the study area was completely reshaped by human activities (the buildup of Saint-Nazaire shipyard, the polderization of the Montoir Bay and the digging of the northern navigation channel). The northern channel was dug and further deepened and enlarged with time for the need of navigation. The Saint-Nazaire harbor was built up, and the Montoir Bay was polderized using the dredged sediments to extend the harbor. The southern channel was progressively abandoned by the main water flow in favor of the newly dug northern channel, causing the southern shift of the Bilho sandbank and the progressive filling of the southern channel (Figs. 1, 8C). However, because of our dating uncertainties, we are not entirely sure if this period is recorded and if so, where does it start in our sedimentary records. The only evidence of an eventual anthropogenic impact in the sedimentary record is the presence in the upper $50 \mathrm{~cm}$ of core $\mathrm{SC} 03$ of a polygenic and very poorly sorted pebble layer (Facies $F_{B}$, Figs. 4,5 ). Indeed this $5 \mathrm{~cm}$-thick layer appears to be an allochtonous body drastically interrupting silty-clay deposits in a tidal environment (Fig. 5). The pebbles are commonly used for various constructions. We can imagine the use of such pebbles for the construction of dikes supporting the polders (Fig. 1C). Core SC03 is located very closely to this polderized area whereas core SC05 is very close to the Méan mudflat which was spared from this polderization (Fig. 1C). Because of this construction, core SC03 is now probably more sheltered from the direct marine influence leading to calmer hydrodynamics and therefore to finer sedimentation than during the pre-industrial period. Part of these fine sediments is certainly issued from the resuspension of fine particles during the dredging. 


\section{Conclusions}

Our analytical approach permitted to reconstruct the infilling of the inner Loire estuary over the past $\sim 6$ kyrs. By tracking both marine (e.g., tide, storm waves) and fluvial dynamics (e.g., floods), our paleorecords allowed us to connect the upstream Holocene Loire hydrological changes described in Arnaud-Fassetta et al. (2010) and Delaine et al. (2014) to the Holocene sediment deposits downstream off the Loire River mouth emphasized by Proust et al. (2010). The whole dynamics was linked to sea-level variations and to the regional climate regime. Three main periods stand out from our sedimentary records and are summarized in Figure 8:

- From $\sim 6.0$ to $\sim 2.5$ kyrs BP, when sea-level rise slowed down, a large brackish bay extended over and around the study area. The fine-grained tidal rythmites recorded north of the Bilho bank indicated a calm depositional environment, protected from the main riverine influence. From $\sim 5.4$ to 4.0 kyrs BP, the presence of thick flood deposits near the Bilho bank further indicated the dominance of humid conditions.

- From $\sim 2.5$ kyrs BP to $\sim 1850$ AD (pre-industrial state), sea-level stabilized at its present value, and the pre-existing bay was progressively infilled. Near the present day Méan mudflat, the generally homogenous fine-grained sedimentation indicated a sheltered environment. We suppose therefore that the main water flow channel was located south of the Bilho bank. Foraminifera responded to the progressive infilling of the valley by changing assemblages: typical outer estuarine species were dominant at the start of this period. These were progressively replaced by transported species from the adjacent upper continental shelf indicating the channelization of the main entering marine currents. Finally, the dominance of inner estuarine species in the last $\sim 0.5 \mathrm{kyrs}$ indicated the stabilization of the environment to, at least, its pre-industrial state configuration. 
- Since 1850 AD, human impact progressively modified the general landscape of our study area with the construction of the Saint-Nazaire shipyard, the digging of the northern navigation channel and the polderization of the northern Bay. The southern channel was progressively abandoned by the main water flow in favor of the newly dug northern channel, causing the southern migration of the Bilho sandbank and the progressive filling of the southern channel. However, because of our dating uncertainties, we are not entirely sure if this period is recorded in our archives. The only evidence of a probable anthropogenic impact is the presence in one of our cores of an autochthonous polygenic pebble layer drastically interrupting silty-clay deposits on an upper tidal mudflat. We hypothesized that these pebbles were used for the construction, in the middle of the $19^{\text {th }}$ century, of dikes supporting the polders near Saint-Nazaire shipyard.

\section{Glossary}

${ }^{1}$ IGN (Institut Géographique National): French National Geographic Institute.

${ }^{2}$ UDEM2008: Unified Digital Elevation Model of the Loire estuary issued from compilation of Lidar and bathymetric data.

${ }^{3}$ GIP Loire Estuaire (Groupement d'Intérêt Public Loire Estuaire): A Group of Public Interest having a similar mission as an environmental observatory. Its role is to structure the existing data on the Loire estuarine ecosystem, the acquisition of new data and the regular publication and diffusion of scientific reviews. http://www.loire-estuaire.org.

${ }^{4}$ GPMNSN (Grand Port Maritime de Nantes Saint-Nazaire): Nantes-Saint-Nazaire seaport.

${ }^{5}$ SEMHABEL (Suivi Environnemental des Micro-Habitats Benthiques de 1'Estuaire de la Loire $=$ Environmental Monitoring of Benthic foraminiferal Habitats of the Loire Estuary): A scientific project financed by the FEDER (European Regional Development Fund) through the support of the Masterplan Plan Loire Grandeur Nature from 2012 to 2013 (project leader: Meryem Mojtahid). The main objective of this project was to analyze for the first time the spatial distribution of benthic foraminifera in the Loire estuary together with the study of morpho-sedimentological and geochemical characteristics of their habitats.

${ }^{6}$ RS2E (Réseau de Suivi et de Surveillance Environnemental = Environmental monitoring network): This Project is led by OSUNA (The Pays de la Loire Observatory of Earth 
Sciences) (project leader: Patrick Launeau) from 2012 to 2015. The aim of this project is to set up a routine monitoring of key environmental parameters for the establishment of a long term updated inventory following three axes: a) the protection of the marine coast and the Loire riverbanks, b) the biogeochemical functioning of the Loire estuarine mudflats, and c) the pollution of the watershed near the Loire estuary. http://www.osuna.univ-nantes.fr.

7 CM96 (Côte Marine 96): French marine altitudinal reference. The zero elevation corresponds to the lowest low tide level (LLTL).

${ }^{8}$ IFREMER (Institut Français de Recherche et d'Exploitation de la Mer): French Research Institute for the Exploitation of the Sea.

${ }^{9}$ BRGM (Bureau de Recherches Géologiques et Minières): French Office of Mining and Geological Research.

\section{Acknowledgments}

This study makes part of a 3-years $\mathrm{PhD}$ thesis performed by the first author, and financed by the French Ministry of Higher Education and Research. Additional financial support was provided by the Nantes Saint-Nazaire seaport $\left(\mathrm{GPMNSN}^{4}\right)$ and by the OSUNA (Nantes Atlantic Observatory of Earth Sciences - CNRS-INSU / IN2P3) through the RS2E program (supported by the Region of Pays de la Loire). We would like to thank the Laboratory of sedimentary analysis of IFREMER ${ }^{9}$ Brest for giving us access to their analytical platform. The authors also thank the GIP Loire estuary for providing us the UDEM $2008^{2}$. 


\section{References}

Allen, J.R.L., 2000. Morphodynamics of Holocene salt marshes: a review sketch from the Atlantic and Southern North Sea coasts of Europe. Quat. Sci. Rev. 19, 1155-1231. doi:10.1016/S0277-3791(99)00034-7.

Altenbach, A.V., Pflaumann, U., Schiebel, R., Thies, A., Timm, S., Trauth, M. 1999. Scaling percentages and distributional patterns of benthic foraminifera with flux rates of organic carbon. J. Foramin. Res. 29, 173-185.

Angulo, R.J., De Souza, M.C., Assine, M.L., Pessenda, L.C.R., Disaró, S.T., 2008. Chronostratigraphy and radiocarbon age inversion in the Holocene regressive barrier of Paraná, southern Brazil. Mar. Geol. 252, 111-119. doi:10.1016/j.margeo.2008.03.006.

Arnaud-Fassetta, G., Carcaud, N., Castanet, C., Salvador, P.-G., 2010. Fluviatile palaeoenvironments in archaeological context: Geographical position, methodological approach and global change - Hydrological risk issues. Quatern. Int., Landscape Evolution and Geoarchaeology 216, 93-117. doi:10.1016/j.quaint.2009.03.009.

Barbaroux, L., 1972a. Analyse de tendance des salinités dans une carotte estuarienne. Contrôle par corrélations. Bulletin UOF, 8, , 37-90.

Barbaroux, L., 1972b. Contribution de la microscopie électronique à l'étude des sables et des vases. S.F.M.E., colloque annuel, Nantes, France,24-35.

Barbaroux, L., Gallenne, B., Ottmann, F., Margerel, J.-P., 1974a. Évolution de l'estuaire de la Loire au Quaternaire. Mém. Inst. Géol. Bass. Aquit., 7, 267-274.

Barbaroux, L., Duplessy, J.-C., Margerel, J.-P., Visset, L., 1974b. Variations climatiques et sédimentologiques récentes (période: Atlantique à Actuel) dans l'estuaire de la Loire. Mise en évidence d'épisodes lagunaires. C.R. Acad. Sci., 278, D, 573-576.

Barbaroux, L., Duplaix, S., Visset, L., 1980a. Les dépôts du Quaternaire récent (Atlantique actuel) et le remaniement flandrien du Weichselien dans la région de Saint Nazaire (Loire Atlantique). Bulletin de l'Institut de Géologie du Bassin d'Aquitaine, 27, 61-85.

Barbaroux, L., Duplaix, S., Visset, L., 1980b. Les alluvions anciennes submergées de la basse Loire dans la région de Saint-Nazaire (Loire Atlantique). Bulletin de l'Institut de Géologie du Bassin d'Aquitaine, 28, 51-70. 
Bond, G., Showers, W., Cheseby, M., Lotti, R., Almasi, P., de Menocal, P., Priore, P., Cullen, H., Hajdas, I., Bonani, G., 1997. A pervasive millennial-scale cycle in north Atlantic Holocene and glacial climates. Science, 278, 1257-1266.

Bouchet, V.M.P., Sauriau P.G., Debenay, J.-P., Mermillod-Blondin, F., Schmidt, S., Amiard, J.-C., Dupas, B., 2009. Influence of the mode of macrofauna-mediated bioturbation on the vertical distribution of living benthic foraminifera: First insight from axial tomodensitometry. J. Exp. Mar. Biol.Ecol. 371, 20-33.

Borja, Á., Dauer, D.M., Elliott, M., Simenstad, C.A., 2010. Medium- and Long-term Recovery of Estuarine and Coastal Ecosystems: Patterns, Rates and Restoration Effectiveness. Estuar. Coast. 33, 1249-1260. doi:10.1007/s 12237-010-9347-5

Boyd, R., Dalrymple, R.W., Zaitlin, B.A., 1992. Classification of coastal sedimentary environments. Sediment. Geol., 80, 139-150.

Brasier, M.D., 1981. Microfossil transport in the tidal Humber basin. In Microfossils from Recent and Fossil Shelf Seas, Neale, P. and Brasier, M.D., Eds. Chichester: Ellis Horwood Ltd., 314-322.

Camacho, S., Moura, D., Connor, S., Scott, D., Boski, T., 2015. Ecological zonation of benthic foraminifera in the lower Guadiana Estuary (southeastern Portugal). Mar. Micropaleontol. 114, 1-18. doi:10.1016/j.marmicro.2014.10.004

Castanet, C., Garcin, M., Lamothe, M., Camerlynck, C., Cyprien, A.L., Carcaud, N., Burnouf, J., 2008. Response of the Middle Loire River to climatic and environmental changes during the last deglaciation (Val d'Orléaans, France). Geophys. Res. Abstracts, 5th European Geosciences Union General Assembly, 10, EGU2008-A-00000.

Caulle, C., Koho, K. A., Mojtahid, M., Reichart, G. J., Jorissen, F. J., 2014. Live (Rose Bengal stained) foraminiferal faunas from the northern Arabian Sea: faunal succession within and 20 below the OMZ, Biogeosciences, 11, 1155-1175, doi:10.5194/bg-11-11552014, 2014.

Chaumillon, E., Tessier, B., Reynaud, J.Y., 2010. Stratigraphic records and variability of incised valleys and estuaries along French coasts. Bull. Société Géologique Fr. 181, 75-85. doi:10.2113/gssgfbull.181.2.75 
Ciffroy, P., Reyss, J.-L., Siclet, F., 2003. Determination of the residence time of suspended particles in the turbidity maximum of the Loire estuary by $7 \mathrm{Be}$ analysis. Estuar., Coast. Shelf S. 57, 553-568. doi:10.1016/S0272-7714(02)00339-6

Clavé, B., 2001. Evolution of holocene coastal paleo-environments (example of the northwestern Aquitaine (S-W France)). PhD Thesis, University of Bordeaux I, France, 310 p.

Colman, S. M., G. Jones, A. Forester, R. M. , Foster, D. S., 1990. Holocene paleoclimatic evidence and sedimentation rates from a core in southwestern Lake Michigan. Journal of Paleolimnology, 4, 269-284.

Colman, S.M., Baucom, P.C., Bratton, J.F., Cronin, T.M., McGeehin, J.P., Willard, D., Zimmerman, A.R., Vogt, P.R., 2002. Radiocarbon Dating, Chronologic Framework, and Changes in Accumulation Rates of Holocene Estuarine Sediments from Chesapeake Bay. Quatern. Res. 57, 58-70. doi:10.1006/qres.2001.2285

Dalrymple, R.W., Zaitlin, B.A., Boyd, R., 1992. Estuarine facies models: conceptual basis and stratigraphic implications. J. Sediment. Petrol. 62, 1130-1146.

Dalrymple, R., Boyd, R., Zaitlin, B.A., 1994. Incised valley system: origin and sedimentary sequences. Soc. Econ. Pa. 51, 45-60

Davis R.A., Dalrymple R.W., 2012. Principle of tidal sedimentology. Springer Ed., 609 pp. DOI 10.1007/978-94-007-0123-6

Decours, C., 2006. Le port de Nantes à 3000 ans, sixth ed. Relié, Paris.

Delaine, M., Armynot du Chatelet, E., Bout-Roumazeilles, V., Goubert, E., Le Cadre, V., Recourt, P., Trentesaux, A., Arthuis, R., 2014. Multiproxy approach for Holocene paleoenvironmental reconstructions from microorganisms (testate amoebae and foraminifera) and sediment analyses: The infilling of the Loire Valley in Nantes (France). The Holocene 25, 407-420. doi:10.1177/0959683614561883

De Rijk, S. and Troelstra, S.R. 1999. The application of a foraminiferal actuo-facies model to salt-marsh cores. Palaeogeogr., Palaeocl. 149, 59-66. 
De Souza, M.C., Angulo, R.J., Assine, M.L., de Castro, D.L., 2012. Sequence of facies at a Holocene storm-dominated regressive barrier at Praia de Leste, southern Brazil. Mar. Geol. 291-294, 49-62. doi:10.1016/j.margeo.2011.10.009

Elliott, M., Quintino, V., 2007. The Estuarine Quality Paradox, Environmental Homeostasis and the difficulty of detecting anthropogenic stress in naturally stressed areas. Mar. Pollut. Bull. 54, 640-645. doi:10.1016/j.marpolbul.2007.02.003

Fatela, F., Taborda, R., 2002. Confidence limits of species proportions in microfossil assemblages. Mar. Micropal. 45, 169-174. doi:10.1016/S0377-8398(02)00021-X

Fatela, F., Moreno, J., Moreno, F., Araújo, M.F., Valente, T., Antunes, C., Taborda, R., Andrade, C., Drago, T., 2009. Environmental constraints of foraminiferal assemblages distribution across a brackish tidal marsh (Caminha, NW Portugal). Mar. Micropal. 70, 7088.

Fenies, H., Tastet, J.-P., 1998. Facies and architecture of an estuarine tidal bar (the Trompeloup bar, Gironde Estuary, SW France). Mar. Geol. 150, 149-169. doi:10.1016/S0025-3227(98)00059-0

Gallenne, B., 1974. Les accumulations turbides de l'estuaire de la Loire-Étude de la crème de vase. unpublished PhD Thesis, University of Nantes, France, 322 p.

Ghosh, A., Saha, S., Saraswati, P.K., Banerjee, S., Burley, S., 2009. Intertidal foraminifera in the macro-tidal estuaries of the Gulf of Cambay: Implications for interpreting sea-level change in palaeo-estuaries. Mar. Petrol. Geology 26, 1592-1599. doi:10.1016/j.marpetgeo.2008.08.002

Gooday, A.J., 1994. The biology of deep-sea foraminifera: a review of some advances and their applications in paleoceanography. Palaios 9: 14-31

Gooday, A.J., Bernhard, J.M., Levin, L. A., Suhr, S. B., 2000. Foraminifera in the Arabian Sea oxygen minimum zone and other oxygen-deficient settings: taxonomic composition, diversity, and relation to metazoan faunas, Deep-Sea Res. Pt. II, 47, 25-54.

Goslin, J., B. Van Vliet-Lanoë, C. Delacourt, A. Fernane, E. Gandouin, A. Hénaff, A. Penaud, P. Stephan, S. Suanez, 2013. Holocene relative sea-level changes in western Brittany 
(France) between 7600 and 4000 cal. BP: reconstitution from basal-peat deposits. Géomorphologie: relief Process. Environ. 4 , 425-444

Goslin, J., Van Vliet Lanoë, B., Spada, G., Bradley, S., Tarasov, L., Neill, S., Suanez, S., 2015. A new Holocene relative sea-level curve for western Brittany (France): Insights on isostatic dynamics along the Atlantic coasts of north-western Europe. Quaternary Sci. Rev. 129, 341-365. doi:10.1016/j.quascirev.2015.10.029

Green, M.A., Aller, R.C., Aller, J.Y., 1993. Carbonate dissolution and temporal abundances of Foraminifera in Long Island Sound sediments. Limnol. Oceanogr. 38, 331-345. doi:10.4319/1o.1993.38.2.0331

Hammer, O., Harper, D.A.T., Ryan, P.D., 2001. PAST: Paleontological statistics software package for education and data analysis. Paleontol. Electron. 4 (1), 1-9.

Hayward, B.W., Grenfell, H.R., Reid, C.M., Hayward, K.A., 1999. Recent New Zealand Shallow-water Benthic Foraminifera: Taxonomy, Ecologic Distribution, Biogeography, and Use in Paleoenvironmental Assessment, Institute of Geological \& Nuclear Sciences, Lower Hutt, New Zealand (monograph 21), 264 pp.

Hua, Q., Barbetti, M., Rakowski, A. Z., 2013. Atmospheric Radiocarbon for the Period 19502010. Radiocarbon 55, 2059-2072.doi:10.2458/azu_js_rc.v55i2.16177

Jervey, M.T. 1988. Quantitative geological modeling of siliciclastic rock sequences and their seismic expression. In Wilgus, C.K. Hasting, B.S., Kendall, C.G.St, C., Posamentier, H.W., Ross, C.A., Van Wagoner, J.C., eds, Sea level changes: an integrated approach. Tulsa, OK, Society of Economic Paleontologist and Mineralogist. Special Publication, 42, 47-69.

Jorissen, F. J., de Stigter, H. C., Widmark, J. G. V., 1995. A conceptual model explaining benthic foraminiferal microhabitats, Mar. Micropal., 26, 3-15.

Jorissen, F.J., Fontanier, C., and Thomas, E., 2007. Chapter Seven Paleoceanographical Proxies Based on Deep-Sea Benthic Foraminiferal Assemblage Characteristics, in Developments in Marine Geology, Volume 1, edited by Claude Hillaire-Marcel and Anne De Vernal, Elsevier, 263-325. 
Kotilainen, A.T., Arppe, L., Dobosz, S., Jansen, E., Kabel, K., Karhu, J., Kotilainen, M.M., Kuijpers, A., Lougheed, B.C., Meier, H.E.M., Moros, M., Neumann, T., Porsche, C., Poulsen, N., Rasmussen, P., Ribeiro, S., Risebrobakken, B., Ryabchuk, D., Schimanke, S., Snowball, I., Spiridonov, M., Virtasalo, J.J., Weckström, K., Witkowski, A., Zhamoida, V., 2014. Echoes from the Past: A Healthy Baltic Sea Requires More Effort. AMBIO 43, 6068. doi:10.1007/s13280-013-0477-4

Lambeck, T., 1997. Sea-level change along the French Atlantic and channel coasts since the time of the last glacial maximum. Palaeogeography Palaeoclimatology Palaeoecolecology, 129 (1-2) (1997), 1-22

Leorri, E., Martin, R., McLaughlin, P., 2006. Holocene environmental and parasequence development of the St. Jones Estuary, Delaware (USA): Foraminiferal proxies of natural climatic and anthropogenic change. Palaeogeogr., Palaeoec. 241, 590-607. doi:10.1016/j.palaeo.2006.04.011.

Leorri, E., Fatela, F., Cearreta, A., Moreno, J., Antunes, C., Drago, T., 2011. Assessing the performance of a foraminifera-based transfer function to estimate sea-level changes in northern Portugal. Quatern. Res., 75, 278-287.

Leorri, E., A. Cearreta, G. Milne, 2012. Field observations and modeling of Holocene sealevel changes in the southern Bay of Biscay: implications for understanding current rates of relative sea-level change and vertical land motion along the Atlantic coast of SW Europe. Quaternary Sci. Rev., 42, 59-73

Lougheed, B. C., Filipsson, H.L., Snowball, I., 2013. Large spatial variations in coastal 14C reservoir age - A case study from the Baltic Sea. Clim. Past 9, 1015-1028. doi:10.5194/cp9-1015-2013.

Maillet, G.M., Vella, C., Provansal, M., Sabatier, F. 2006. Connections between the Rhône River and its delta (part 2): changes in the Rhône delta coastline since the beginning of the $18^{\text {th }}$ century. Géomorphologie: relief, processus, environnement, 2/2006, 125-140.

McGowan, S.A., Baker, R.G., 2014. How past sea-level changes can inform future planning: A case study from the Macleay River estuary, New South Wales, Australia. The Holocene 0959683614544055. doi:10.1177/0959683614544055 
Melis R. , Covelli S., 2013. Distribution and morphogical abnormalities of recent foraminifera in the Marano and Grado Lagoon (North Adriatic Sea, Italy). Mediterranean Marine Science, 14/1, 432-450.

Mignot, C., 1993. Bilan de 1'Hydrologie et de 1'hydrosédimentaire de l'estuaire de la Loire au cours des deux dernières décennies. A.P.E.E.L., Charenton-Le-Pont, France, 210 p.

Milliman, J.D. and Ren, M., 1995. River flux tot he sea: impact of human intervention on river systems and adjacent coastal area. In Eisma (ed.), Climate Change: impact on coastal habitation, CRC Press., Boca Raton (Florida), 57-83.Mojtahid, M., Jorissen, F.J., Garcia, J., Schiebel, R., Michel, E., Eynaud, F., Gillet, H., Cremer, M., Diz Ferreiro, P., Siccha, M., Howa, H., 2013. High resolution Holocene record in the southeastern Bay of Biscay: Global versus regional climate signals. Palaeogeogr. Palaeoecol. 377, 28-44. doi:10.1016/j.palaeo.2013.03.004.

Mojtahid, M., Geslin, E., Coynel, A., Gorse, L., Vella, C., Davranche, A., Zozzolo, L., Blanchet, L., Bénéteau E., Maillet G., 2016. Spatial distribution of living (Rose Bengal stained) benthic foraminifera in the Loire estuary (western France). J. Sea Res. doi:10.1016/j.seares.2016.02.003

Moreno, J., Fatela, F., Leorri, E., De la Rosa, J.M., Pereira, I., Araújo, M.F., Freitas, M.C., Corbett, D.R., Medeiros, A., 2014. Marsh benthic Foraminifera response to estuarine hydrological balance driven by climate variability over the last $2000 \mathrm{yr}$ (Minho estuary, NW Portugal). Quatern. Res. 82, 318-330. doi:10.1016/j.yqres.2014.04.014

Morzadec-Kerfourn, M.-T., 1974. Variation de la ligne de rivage armoricaine au Quaternaire. Analyses polliniques de dépôts organiques littoraux. $\mathrm{PhD}$ thesis University of Rennes $1, \mathrm{p}$. 208

Moodley, L., Hess, C., 1992. Tolerance of Infaunal Benthic Foraminifera for Low and High Oxygen Concentrations. Biol. Bull. 183, 94-98. doi:10.2307/1542410

Mougani, B., 1982. Redistribution des sédiments consécutive à des travaux d'aménagement: dépôt de dragage sur le banc de Bilho dans l'estuaire de la Loire. $\mathrm{PhD}$ thesis University of Nantes, p. 143.

Murray, J.W., 2006. Ecology And Applications of Benthic Foraminifera. Cambridge University Press, Cambridge, 426 p. 
Murray, J.W., Hawkins, A.B., 1976. Sediment transport in the Severn Estuary during the past 8,000 - 9,000 years. J. Geol. Soc., London 132, 385-398.

Murray, J.W., Alve, E., 1999. Natural dissolution of shallow water benthic foraminifera: taphonomic effects on the palaeoecological record. Palaeogeogr. Palaeoecol. 146:195-209.

Ottmann, F., Alix, Y., Limasset, O., 1968. Sur le lit ancien de la Loire, dans son cours inférieur. Bull. B.R.G.M., (2), 1, 2, p. 27-56.

Perillo, G.M.E., 1995. Definition and geomorphologic classifications of estuaries In: Perillo, G.M.E. (Eds.), Geomorphology and Sedimentology of Estuaries, Development in Sedimentology 53, Elsevier Science BV, Amsterdam, pp. 17-47

Philippsen, B., 2013. The freshwater reservoir effect in radiocarbon dating. Heritage Science 1, 24. doi:10.1186/2050-7445-1-24

Piña-Ochoa, E., Koho, K.A., Geslin, E., Risgaard-Petersen, N., 2010. Survival and life strategy of the foraminiferan Globobulimina turgida through nitrate storage and denitrification. Mar Ecol Prog Ser., 417, 39-49. doi:10.3354/meps08805.

Proust, J.N., Renault, M., Gennoc, P., and Thinon, I., 2010. Sedimentary architecture of the Loire River drowned valleys of the French Atlantic shelf. Bull. Soc. Géol. Fr. 181, 129149. doi:10.2113/gssgfbull.181.2.129.

Rea, D. K. and Colman, S. M., 1995. Radiocarbon ages of pre-bomb clams and the hard-water effect in Lakes Michigan and Huron. J. Paleolimn., 14: 89-91.

Reaves, C.M., 1986. Organic matter metabolizability and calcium carbonate dissolution in nearshore marine muds. J. of Sediment. Petrol., 56, 486-494.

Reimer, P. J., Brown, T. A., and Reimer, R. W. 2004. Discussion: Reporting and calibration of Post-Bomb 14C Data. Radiocarbon 46, 1299-1304.

Reimer, P.J., Bard, E., Bayliss, A., Beck, J.W., Blackwell, P.G., Ramsey, C.B., Buck, C.E., Cheng, H., Edwards, R.L., Friedrich, M., Grootes, P.M., Guilderson, T.P., Haflidason, H., Hajdas, I., Hatté, C., Heaton, T.J., Hoffmann, D.L., Hogg, A.G., Hughen, K.A., Kaiser, K.F., Kromer, B., Manning, S.W., Niu, M., Reimer, R.W., Richards, D.A., Scott, E.M., Southon, J.R., Staff, R.A., Turney, C.S.M., Plicht, J. van der, 2013. IntCal13 and Marine13 
Radiocarbon Age Calibration Curves 0-50,000 Years cal BP. Radiocarbon 55, 1869-1887. doi:10.2458/azu_js_rc.55.16947.

Reineck, H.E., Singh, I.B., 1973. Depositional Sedimentary Environments, 1rst ed. Springer Verlag, New York, 439 p.

Schröder-Adams, C.J., 2006. Estuaries of the past and present: A biofacies perspective. Sedimentary Geology, 190, 289-298.

Scott, D.B., Medioli, F.S., 1980. Quantitative studies of marsh foraminiferal distributions in Nova Scotia: implications for sea level studies. Special Publication - Cushman Foundation for Foraminiferal Research 17, 58 pp.

Sen Gupta, B.K., Machain-Castillo, M.L., 1993. Benthic foramindera in oxygen-poor habitats Mar. Micropal., 20: 183-201.

Soares, C., Sobral P., 2009. Bioturbation and erodibility of sediments from the Tagus estuary. J. Coastal Res. 56, 1429-1433.

Spencer, C.D., Plater, A.J., Long, A.J., 1998. - Rapid coastal change during the Mid- to Late Holocene: The record of barrier estuary sedimentation in the Romney Marsh region, Southeast England. The Holocene, 8 (2), 143-163.

Stéphan, P., Goslin, J., 2014. Evolution du niveau marin relatif à l'Holocene le long des côtes françaises de l'Atlantique et de la Manche : réactualisation des données par la méthode des «sea-level index points » Quaternaire, 25 (4), 295-312

Stuiver, M., Reimer, P.J., 1993. Extended 14C Data Base and Revised Calib 3. 0 14C Age Calibration Program. Radiocarbon 35, 215-230.

Talke, S.A., de Swart, H.E., de Jonge, V.N., 2009. An Idealized Model and Systematic Process Study of Oxygen Depletion in Highly Turbid Estuaries. Estuar Coast. 32, 602-620. doi:10.1007/s12237-009-9171-y

Ters, M., 1973. Les variations du niveau marin depuis 10000 ans, le long du littoral atlantique français. 9e Congrès INQUA, suppl. Bull. A.F.E.Q., p. 114-135.

Ters, M., 1986. Variations in Holocene sea level on the French Atlantic coast and their climatic significance M.R. Rampino, J.E. Sanders, W.S. Newman, L.K. Königsson (Eds.), 
Climate: History, Periodicity and Predictability, Van Nostrand Reinhold, New York (1986), pp. 204-237

Ters, M., Planchais, N., Azema, C., 1968. L'évolution de la basse vallée de la Loire, à l'aval de Nantes, à la fin du Wùrm et pendant la transgression flandrienne. Bull. A.F.E.Q., 3, p. 217-246.

Tessier, B., 1993. Upper intertidal rhythmites in the Mont-Saint-Michel Bay (NW France): Perspectives for paleoreconstruction. Mar. Geol. 110, 355-367. doi:10.1016/00253227(93)90093-B

Thibault de Chanvalon, A., Metzger, E., Mouret, A., Cesbron, F., Knoery, J., Rozuel, E., Launeau, P., Nardelli, M.P., Jorissen, F.J., Geslin, E., 2015. Two-dimensional distribution of living benthic foraminifera in anoxic sediment layers of an estuarine mudflat (Loire estuary, France). Biogeosciences 12, 6219-6234. doi:10.5194/bg-12-6219-2015

Traini, C., Menier, D., Proust, J.-N., Sorrel, P., 2013. Transgressive systems tract of a ria-type estuary: The Late Holocene Vilaine River drowned valley (France). Mar. Geol. 337, 140155. doi:10.1016/j.margeo.2013.02.005

Traini, C., Proust, J.-N., Menier, D., Mathew, M.J., 2015. Distinguishing natural evolution and human impact on estuarine morpho-sedimentary development: A case study from the Vilaine Estuary, France. Estuar. Coastal Shelf S. 163, Part B, 143-155. doi:10.1016/j.ecss.2015.06.025

Van de Plassche, O., 1991. Coastal submergence of the Netherlands, NW Brittany (France), Delmarva Peninsula (VA, USA) and Connecticut (USA) during the last 5500 to 7500 sidereal years; R. Sabadini (Ed.), Glacial Isostasy, Sea Level and Mantle Rheology, Kluwer, Dordrecht (1991), pp. 285-300.

Van Loon, H., 1693. 8ème carte particulière des côtes de Bretagne qui comprend l'entrée de la Loire et l'Isle de Noirmoutier comme elles paroissent à Basse Mer dans les grandes marées, http://gallica.bnf.fr/.

Vink, A., Steffen, H., Reinhardt, L., Kaufmann, G., 2007. Holocene relative sea-level change, isostatic subsidence and the radial viscosity structure of the mantle of northwest Europe (Belgium, the Netherlands, Germany, southern North Sea). Quaternary Sci. Rev. 26, 32493275. doi:10.1016/j.quascirev.2007.07.014. 
Visset, L., 1973. Étude palynologique des sondages A1 (Montoir) et CX (Saint-NazaireMindin). C.R. Acad. Sci., 277, 2469-2472.

Visset, L. and Barbaroux, L., 1972. Étude palynologique du sondage C II, Mindin, SaintNazaire. C.R. Acad. Sci., 21 A, D, 1269-1271.

Wang, P., Chappell, J., 2001. Foraminifera as Holocene environmental indicators in the South Alligator River, Northern Australia. Quaternary International, Australian Quaternary Studies: A Tribute to Jim Bowler 83-85, 47-62. doi:10.1016/S1040-6182(01)00030-1

Zaitlin, B.A., 1994. Incised-valley systems: origin and sedimentary sequences. Soc. Econ. P. $51,45-60$.

Zaitlin, B.A., Dalrymple, R.W. and Boyd, R., 1994. - The stratigraphic organisation of incised valley systems associated with relative sea-level change. In: R.W. Dalrymple, R.J. Boyd and B.A. Zaitlin (Eds), Incised valley systems: Origin and sedimentary Sequences. SEPM (Soc. Sediment. Geol.) Spec. Publ., Tulsa, 45-60. 


\section{Figure captions}

Figure 1. Location of the study area. A) Salinity domains and morphological subdivisions of the Loire estuary (Gallenne, 1974). B) DEM (Digital Elevation Model) of the Loire estuary and the location of the main cities and geological structures. DEM data are sourced from BD Alti ${ }^{\circledR}\left(\subseteq \mathrm{IGN}^{1}\right)$ for land areas, from UDEM $2008^{2}\left(\mathrm{GIP}^{3}\right.$ Loire estuary) for the inner estuary, and from bathymetric data (GPMNSN ${ }^{4}$ : Nantes/Saint-Nazaire seaport) for the outer estuary. C) DEM of the study area (red rectangle on figure 1B) with the location of the four studied sediment cores. Location of the diagrammatic section of Figure 1D is represented by a dashed line. D) Diagrammatic section of the inner Loire estuary sedimentary infilling modified from Barbaroux et al. (1974a). The present location of the four studied cores is indicated by red arrows.

Figure 2. Recent morphological evolution of the study area since 1693 AD (copy of the original map; Van Loon 1693), illustrated by seven WGS84 referenced maps (1850 to 2008 AD) simplified into four bathymetric ranges (see details of the mapping method in the text). The present location of the four studied cores is indicated.

Figure 3. High definition photos of the four studied cores presented as sections of about $1 \mathrm{~m}$ long. The nine white rectangles underline selected sediment segments numbered in accordance with Figure 4 where they are described in terms of facies. N.A.: Non available core half-sections.

Figure 4. A) Zoom on the nine selected sediment segments (their position along the core sections are presented as white rectangles on Figure 3) allowing the observation of all the eight facies described in the text (paragraph 4.2.1). Colored bars on the right side of each box symbolize the corresponding facies following the same color code as in Figure 5. B) Zoom on facies $F_{G}$ and its schematic description inspired from the ideal bedding succession recording a neap-spring tidal cycle as described by Tessier (1993).

Figure 5. Sediment description of the four studied cores, using the eight sedimentary facies presented in Figure 4 and the same color code. All ages are given in calibrated AMS ${ }^{14} \mathrm{C}$ dates (cal. yrs BP or AD; see Table 3). Cores are displayed in the figure according to their elevation relatively to the LLTL: Lowest Low Tide Level (scale on the left). N.A.: Non available core half-sections. 
Figure 6. Relative abundances of the main (> 5\%) species of benthic foraminifera in core SC05 grouped following the three PCA groups presented in Figure 7. The stratigraphic column $\left({ }^{14} \mathrm{C}\right.$ dates in cal. yrs BP or AD) is drawn on the left part of the figure. The small empty circles placed near the log indicate the location of counted foraminiferal samples. Gray bars indicate samples with less than 10 counted individuals. These samples were discarded from the calculation of foraminiferal relative abundances. N.A.: Non available core halfsections.

Figure 7. Principal Component Analysis (PCA): Projection on the first two axes of the PCA of the $\%$ of the main (>5\%) living benthic foraminiferal species. The samples depths in core SC05 are represented by black dots. A zoom on the low contributors to PCA axes is presented in the red rectangle.

Figure 8. Paleogeographical evolution of the study area from $\sim 6$ kyrs to present. Left panels show paleogeographic maps on which the present day position of the four studied cores is indicated. Right panels propose 3D block-diagrams presenting the hypothetical paleogeographical reconstruction of our sedimentary archives. A) The reconstruction of the coastline during the $\sim 6-2.5$ kyrs time period (maximum flooding due to the Holocene transgression) is based on the Holocene alluvium fluviomarine deposits drawn in Paimboeuf and Saint-Nazaire geological maps (1/50000; $\left.\mathrm{BRGM}^{9}\right)$. B) The 1850 AD historical map represents the pre-industrial period. C) The 2008 AD map shows the modern morphology impacted by human management. 
Plate 1. SEM photographs of most foraminiferal species found downcore SC05. All lettering numbers "a" are spiral sides and all "b" are umbilical sides. 1. Remaneica plicata (Terquem, 1876); 2. Jadammina macrescens (Brady, 1870); 3. Adelosina sp.; 4. Miliolinella subrotunda (Montagu, 1803); 5. Edentostomina sp.; 6. Quinqueloculina lata (Terquem, 1876); 7. Procerolagena clavata (d'Orbigny, 1846); 8. Lagena perlucida (Montagu, 1803); 9. Lagena sulcata (Walker and Jacob, 1798); 10. Homalohedra williamsoni (Alcock, 1865); 11. Fissurina orbignyana (Seguenza, 1862); 12. Favulina melo (d'Orbigny, 1826); 13. Palorbulina mediterranensis (d'Orbigny, 1826); 14. Gavelinopsis praegeri (Heron Allen and Earland, 1913); 15. Asterigerinata mamilla (Williamson, 1858); 16. Ammonia beccarii (Linnaeus, 1758); 17. Ammonia tepida (Cushman, 1926); 18. Ammonia parkinsoniana (d'Orbigny, 1839); 19. Lobatula lobatula (Walker and Jacob, 1798); 20. Haynesina germanica (Ehrenberg, 1840); 21. Haynesina depressula (Walker and Jacob, 1798); 22. Elphidium williamsoni (Haynes, 1973); 23. Elphidium aculeatum (d'Orbigny, 1846); 24. Cribroelphidium excavatum (Terquem, 1876); 25. Elphidium excavatum subsp. Clavatum (Cushman, 1930); 26. Elphidium decipiens (Costa, 1856). 


\section{Table captions}

Table 1. Main characteristics of original historical maps

Table 2. Main characteristics of the four studied cores. Geographic coordinates are given in WGS84 system and depths in meters below LLTL (Lowest Low Tide Level).

Table 3. Radiocarbon dates. All absolutes AMS ${ }^{14} \mathrm{C}$ ages are expressed in radiocarbon years BP and calibrated ages are given in calendar years BP. Because of its post 1950 age, radiocarbon sample Poz-74595 (core SC05; 123-124cm depth) absolute dating is given in pMC (percent of Modern Carbon) and calibrated age is given in years AD. LLTL: Lowest Low Tide Level; TOC: Total Organic Carbon. 

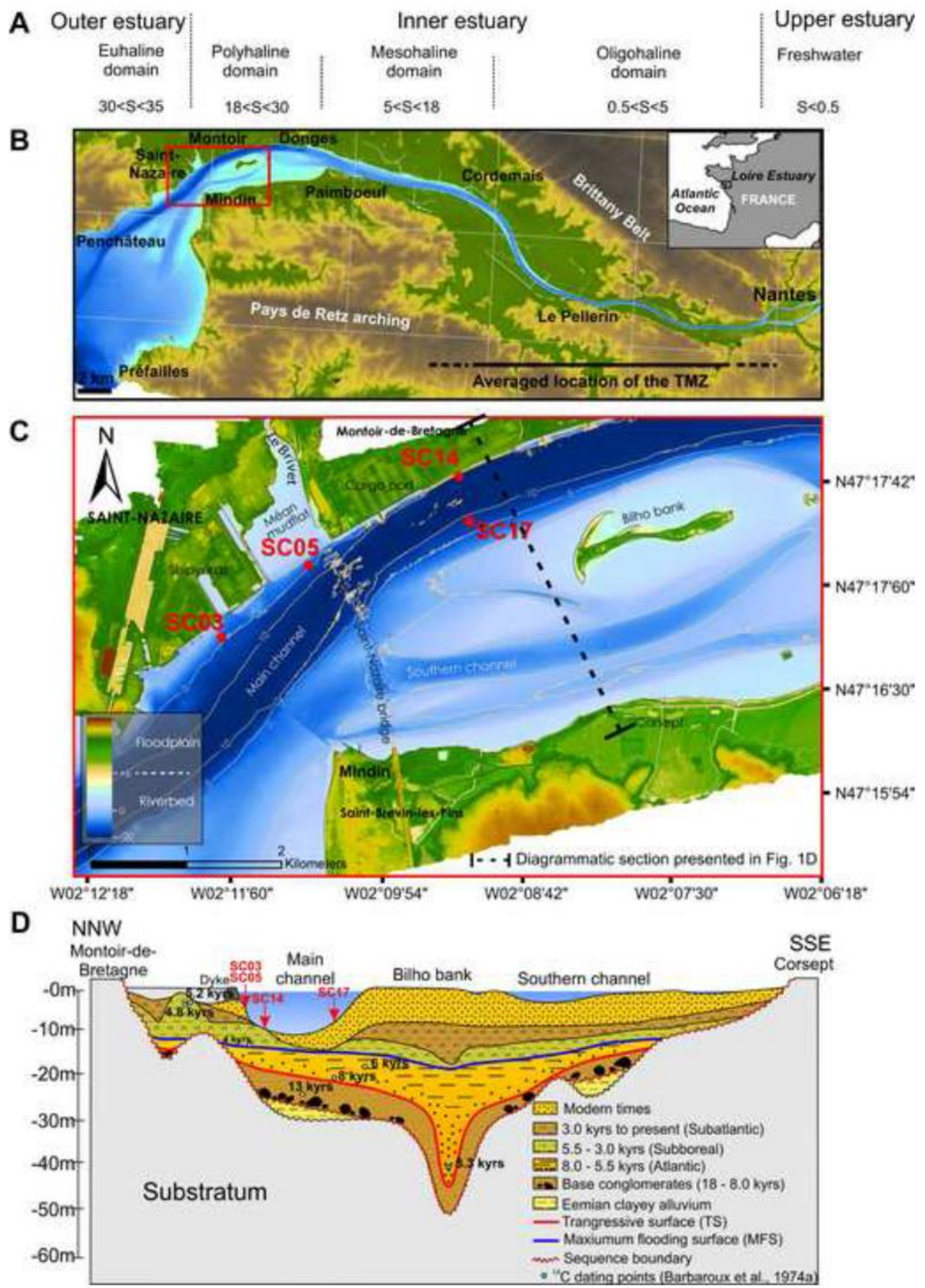

\section{Figure 1}



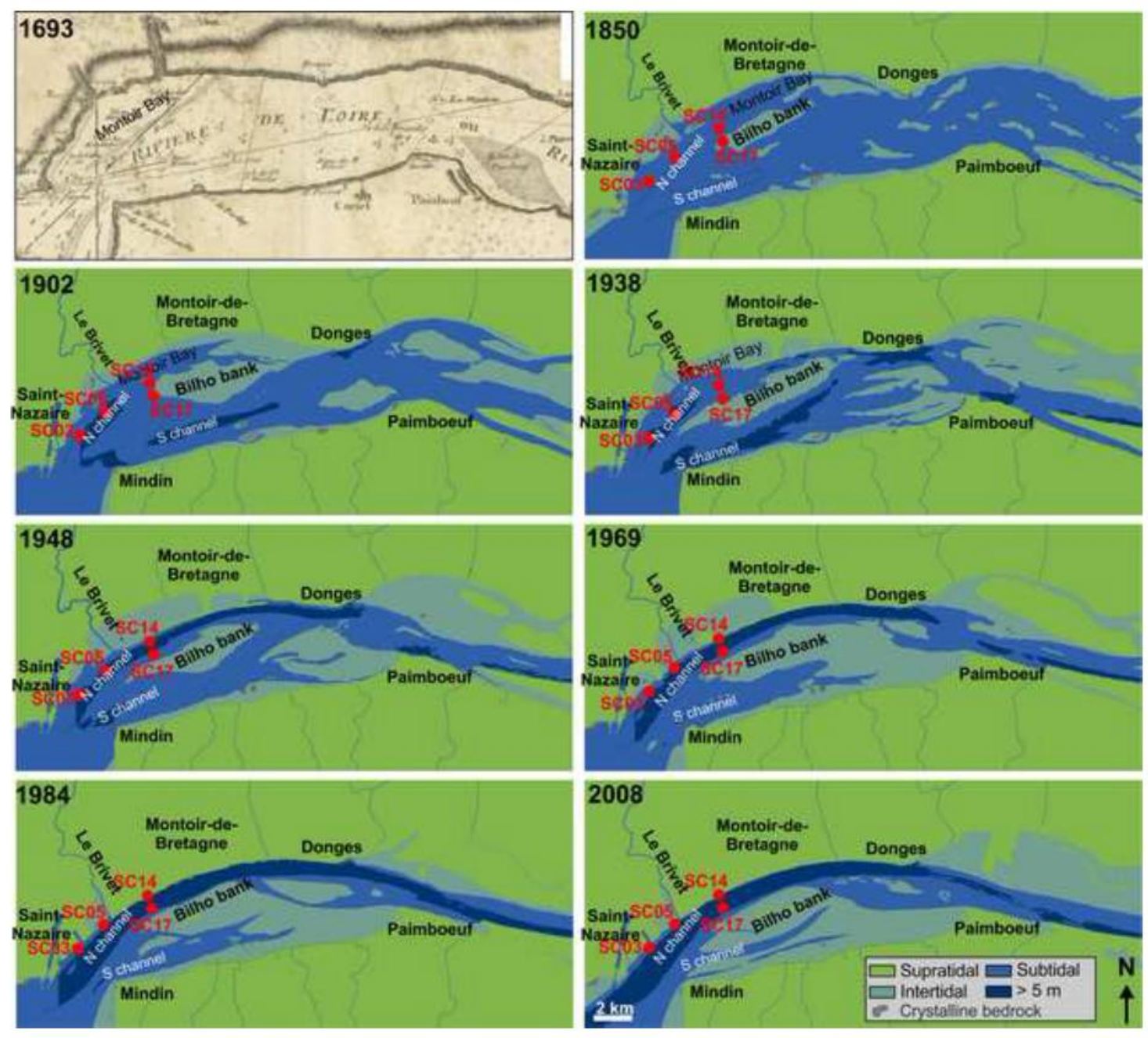

Figure 2

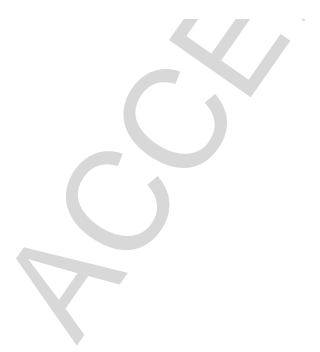



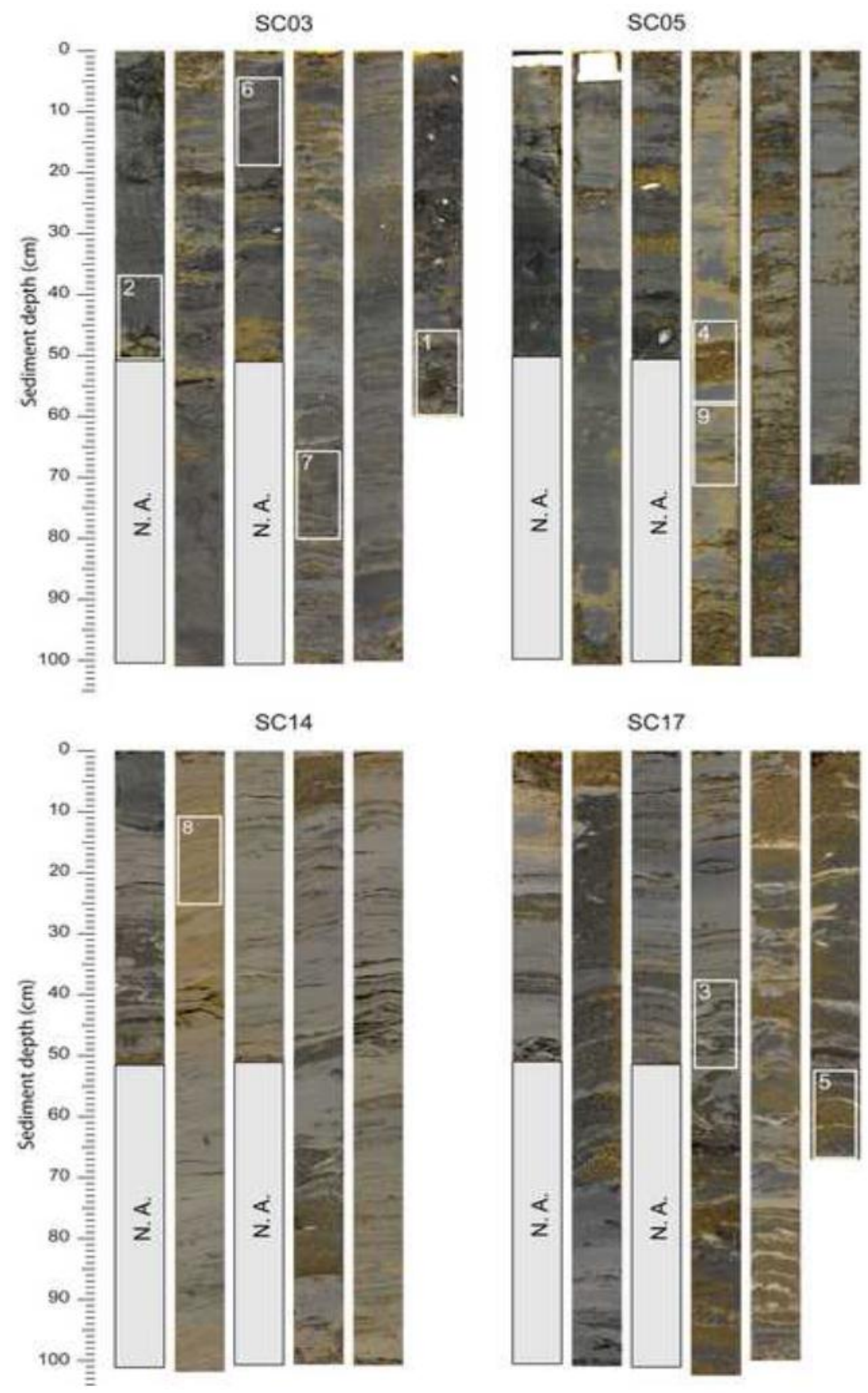

Figure 3 


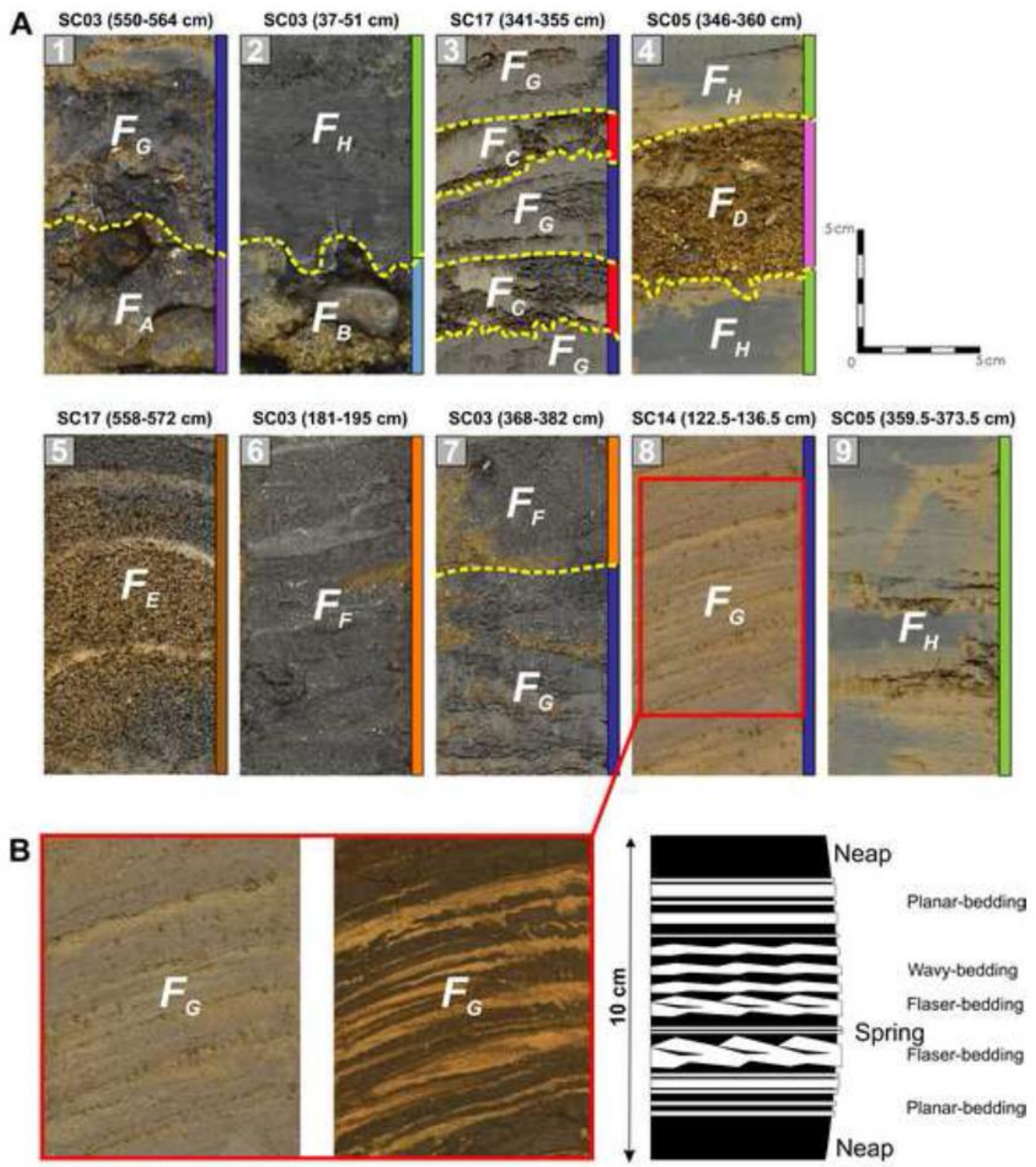

Regular camera photography Geotek MSCL photography

\section{Figure 4}



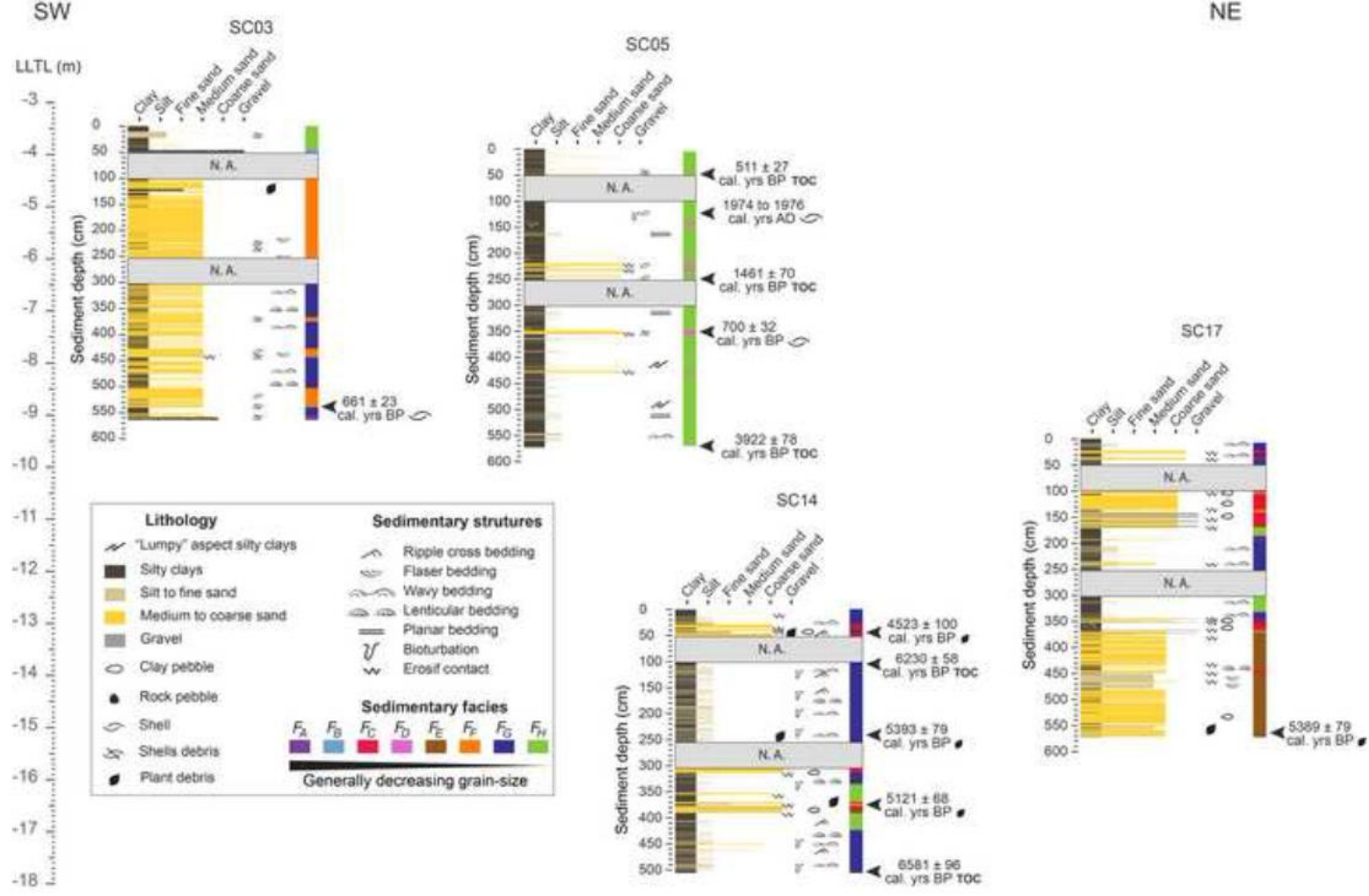

Figure 5 


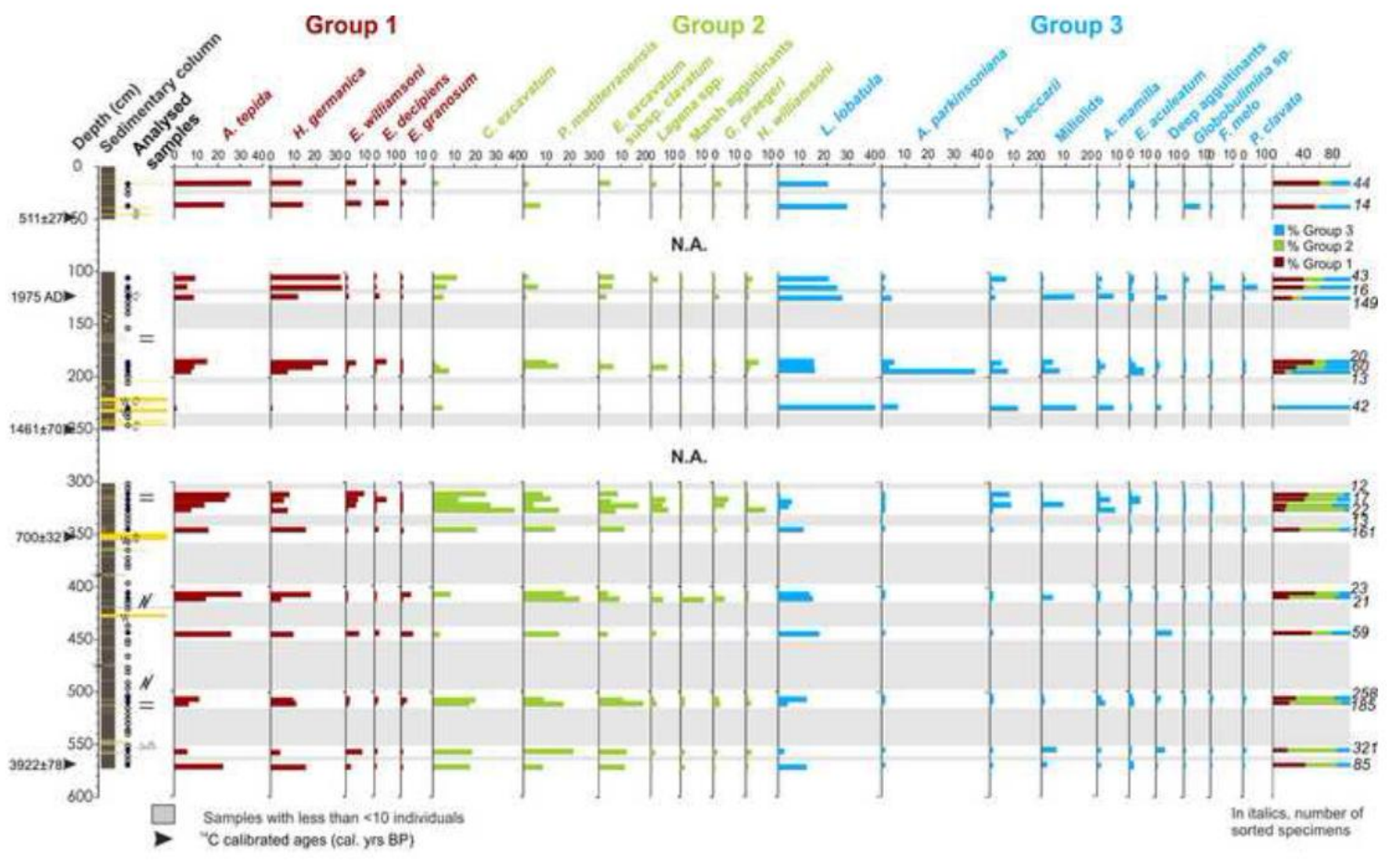

Figure 6 


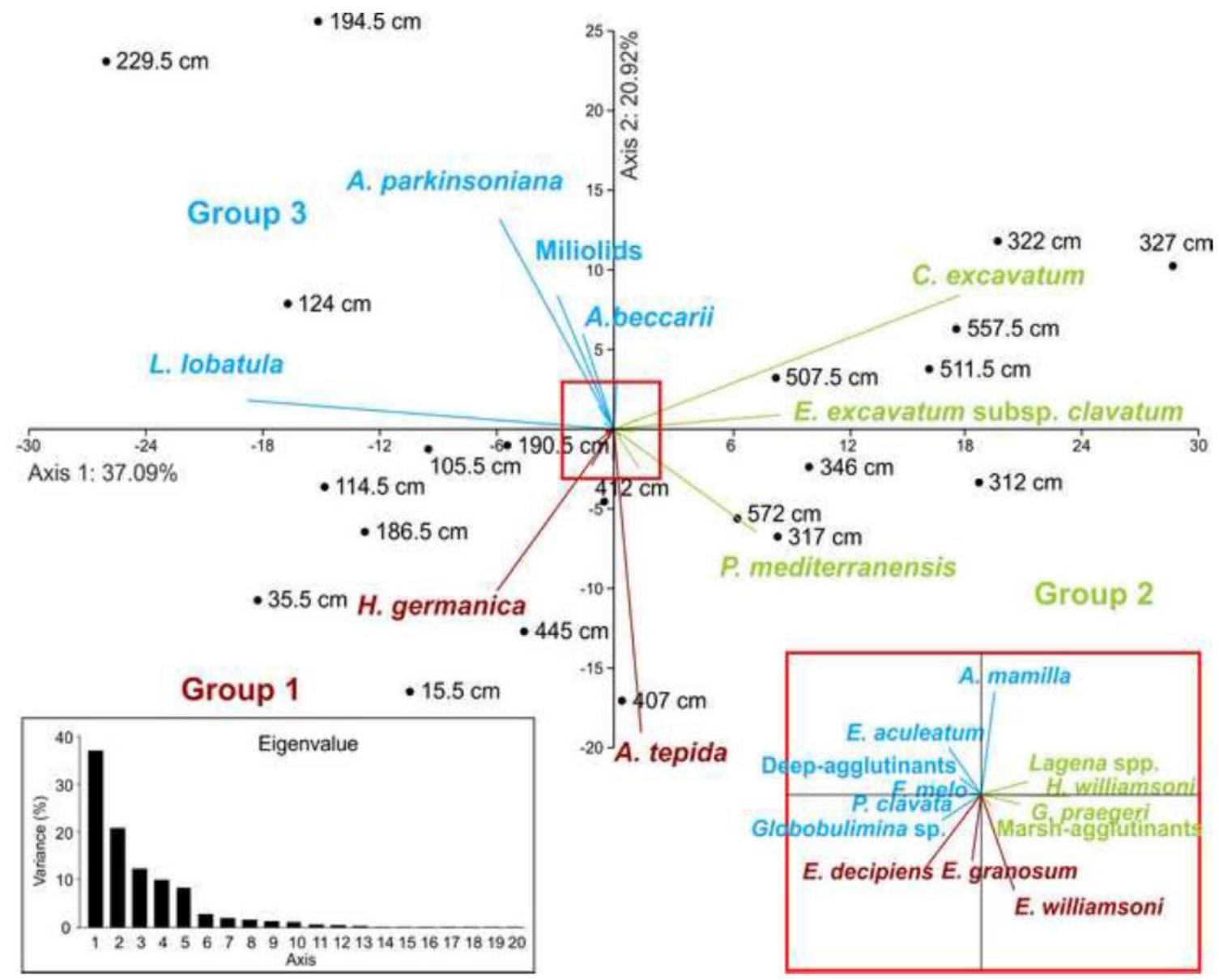

Figure 7 
A From -6 kyrs BP and 2.5 kyrs BP

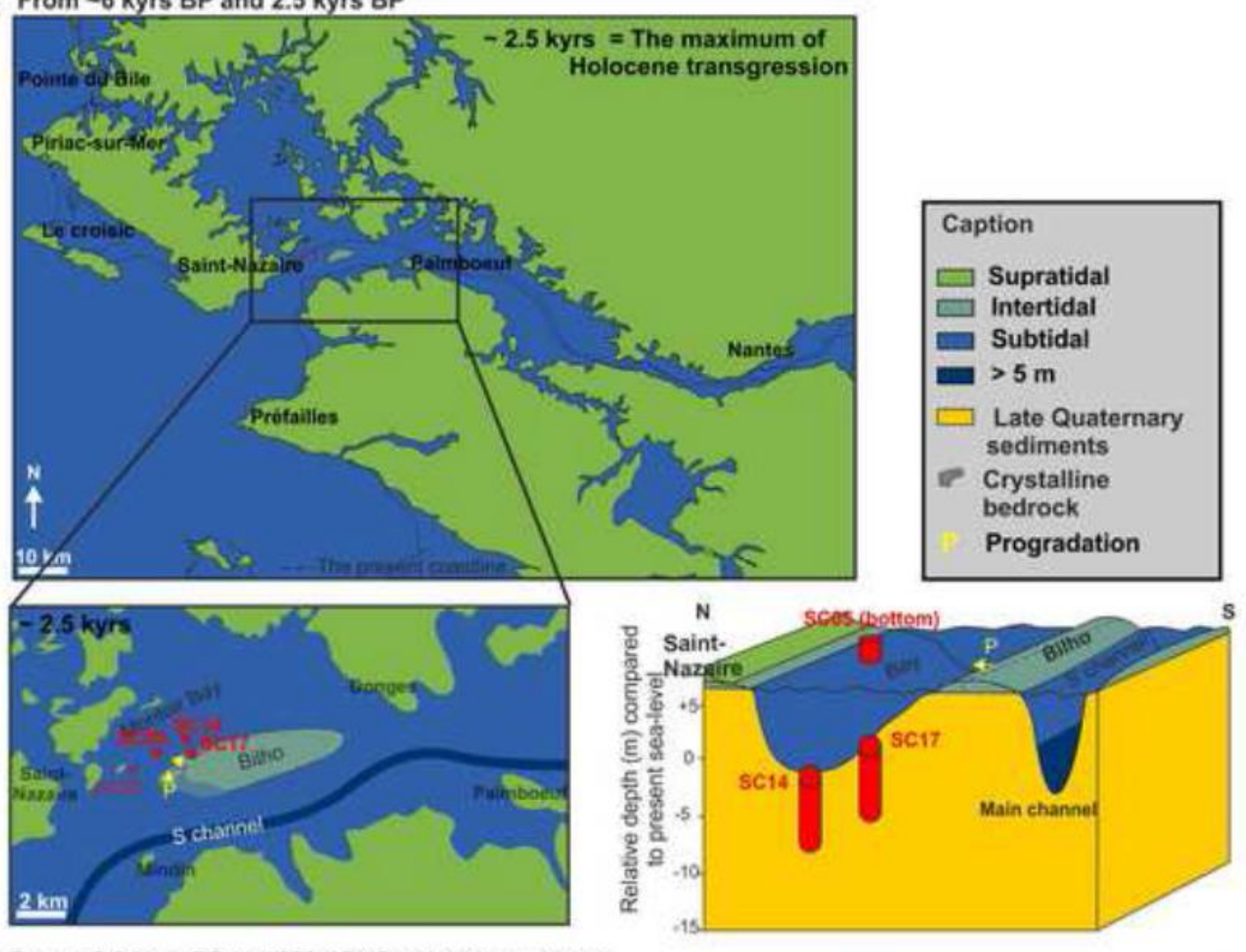

B From -2.5 kyrs BP to $1850 \mathrm{AD}$ (Sea-level = present)
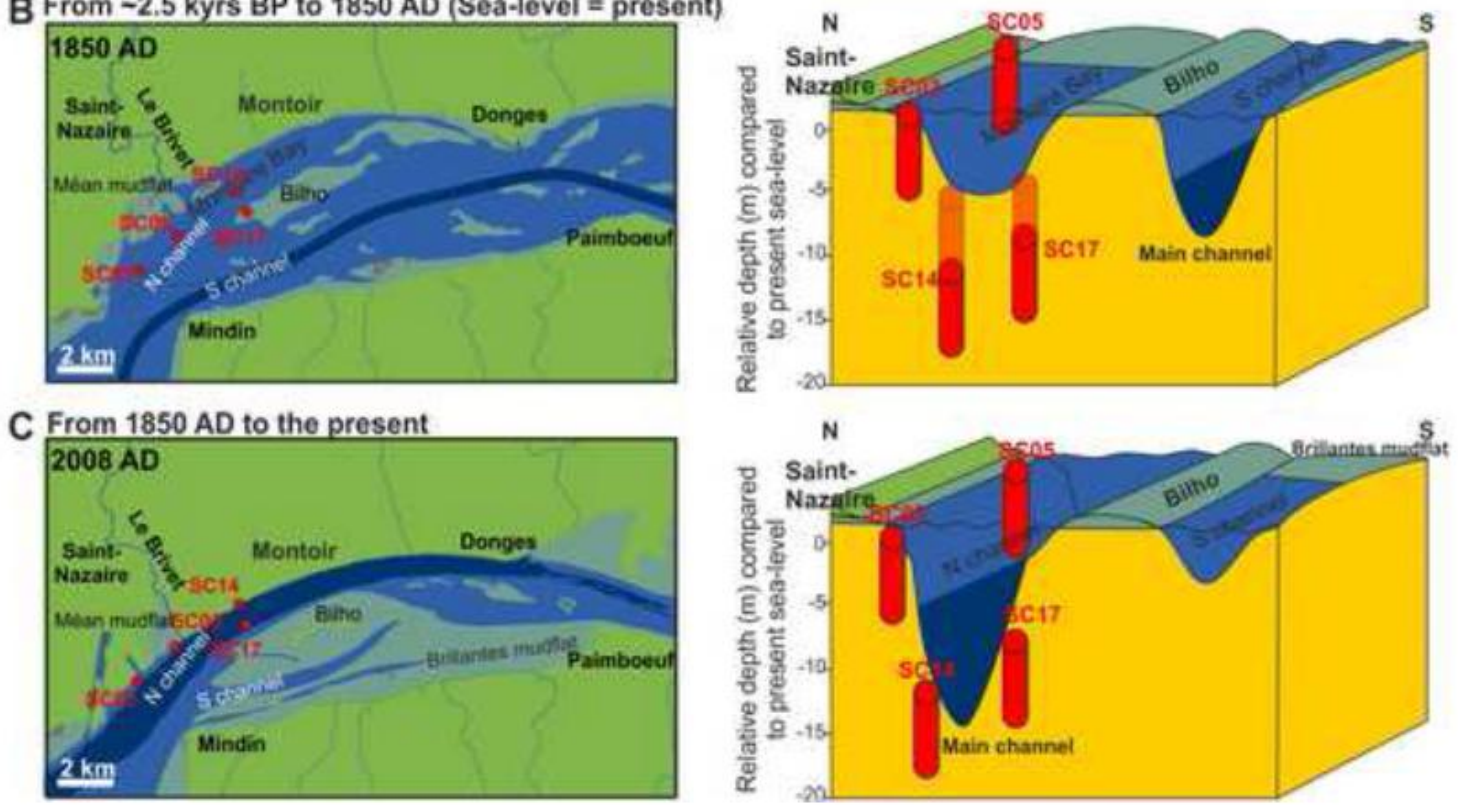

Figure 8 


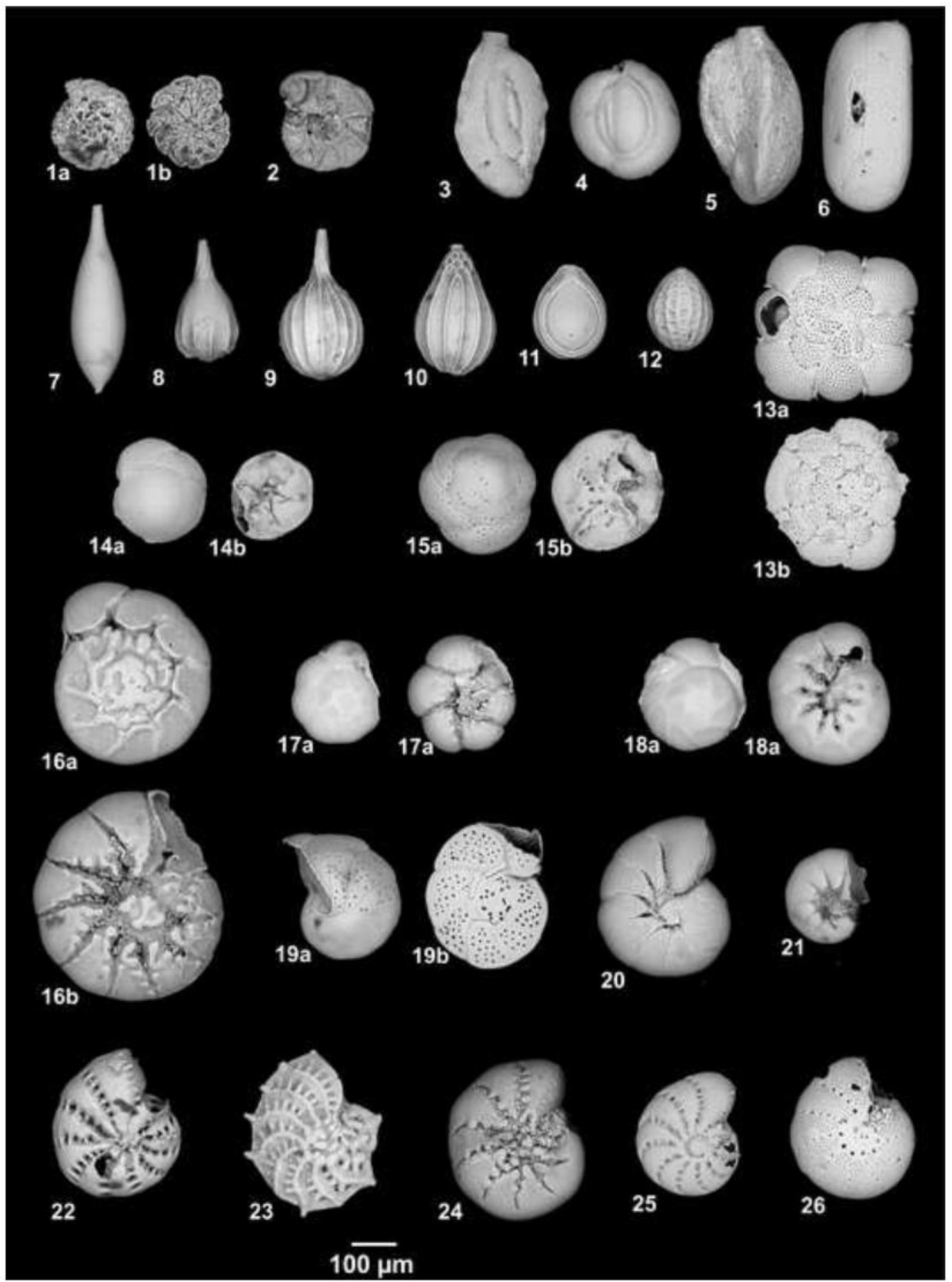

Plate 1 
Table 1. Main characteristics of original historical maps

\begin{tabular}{|c|c|c|c|c|}
\hline $\begin{array}{l}\text { Year } \\
\text { (AD) }\end{array}$ & Map type & $\begin{array}{l}\text { Altitude } \\
\text { reference }\end{array}$ & Source & Online Reference \\
\hline 1693 & Geographical & Not available & Van Loon (1693) & http://gallica.bnf.fr/ \\
\hline 1850 & $\begin{array}{l}\text { Geographical with } \\
\text { indications on tidal } \\
\text { environments }\end{array}$ & Not available & $\operatorname{IGN}^{1}$ & http://www.ign.fr/ \\
\hline 1902 & Bathymetrical & & GPMNSN $^{4}$ & \\
\hline 1938 & Bathymetrical & & GPMNSN $^{4}$ & \\
\hline 1948 & Bathymetrical & & GPMNSN $^{4}$ & \\
\hline 1969 & Bathymetrical & & GPMNSN $^{4}$ & \\
\hline 1984 & Bathymetrical & Zero $\mathrm{CM} 96^{7}=$ & $\mathrm{GPMNSN}^{4}$ & \\
\hline 2008 & UDEM $^{2}$ & LLTL & GIP $^{3}$ Loire estuary & http://www.loire-estuaire.org \\
\hline
\end{tabular}


Table 2. Main characteristics of the four studied cores. Geographic coordinates are given in WGS84 system and depths in meters below LLTL (Lowest Low Tide Level).

\begin{tabular}{cccccc}
\hline Core & N latitude & E longitude & Water depth $(\mathrm{m})(\mathrm{LLTL})$ & Core length $(\mathrm{m})$ & Sampling date \\
\hline SC03 & $47^{\circ} 16^{\prime} 44.10^{\prime \prime}$ & $-2^{\circ} 11^{\prime} 13.20^{\prime \prime}$ & -3.44 & 5.64 & $14 / 01 / 2012$ \\
SC05 & $47^{\circ} 17^{\prime} 10.30^{\prime \prime}$ & $-2^{\circ} 10^{\prime} 31.80^{\prime \prime}$ & -3.90 & 5.73 & $12 / 01 / 2013$ \\
SC14 & $47^{\circ} 17^{\prime} 43.50^{\prime \prime}$ & $-2^{\circ} 9^{\prime} 19.20^{\prime \prime}$ & -12.73 & 5.06 & $12 / 01 / 2014$ \\
SC17 & $47^{\circ} 17^{\prime} 28.10^{\prime \prime}$ & $-2^{\circ} 9^{\prime} 12.90^{\prime \prime}$ & -9.46 & 5.73 & $13 / 01 / 2015$ \\
\hline
\end{tabular}


Table 3. Radiocarbon dates. All absolutes AMS ${ }^{14} \mathrm{C}$ ages are expressed in radiocarbon years BP and calibrated ages are given in calendar years BP. Because of its post 1950 age, radiocarbon sample Poz-74595 (core SC05; 123-124cm depth) absolute dating is given in pMC (percent of Modern Carbon) and calibrated age is given in years AD. LLTL: Lowest Low Tide Level; TOC: Total Organic Carbon.

\begin{tabular}{|c|c|c|c|c|c|}
\hline $\begin{array}{l}\text { Core and lab. } \\
\text { No. }\end{array}$ & $\begin{array}{l}\text { Sample } \\
\text { depth } \\
(\mathrm{cm})\end{array}$ & $\begin{array}{l}\text { Altitu } \\
\text { de } \\
\text { LLTL } \\
\text { (m) }\end{array}$ & $\begin{array}{c}\mathrm{AMS}{ }^{14} \mathrm{C} \text { ages } \\
\text { (radiocarbon } \\
\text { years } \mathrm{BP} \text { ) }\end{array}$ & $\begin{array}{l}\text { Calibrated ages }(2 \sigma)(\mathrm{cal} . \\
\text { yrs BP) }\end{array}$ & Dating material \\
\hline $\begin{array}{c}\text { SC03 (Poz- } \\
70617)\end{array}$ & $538-539$ & -8.83 & $690 \pm 30$ & $638-684$ & Mollusc Mytilus edulis \\
\hline $\begin{array}{c}\text { SC05 (Poz- } \\
75198)\end{array}$ & $48-49$ & -4.39 & $460 \pm 30$ & $484-537$ & TOC \\
\hline $\begin{array}{l}\text { SC05 (Poz- } \\
74595)\end{array}$ & $123-124$ & -5.14 & $\begin{array}{l}140.49 \pm 0.38 \\
(\mathrm{pMC})\end{array}$ & $\begin{array}{l}1973.91 \text { - } 1975.83 \text { (cal. } \\
\text { yrs AD) }\end{array}$ & $\begin{array}{l}\text { Mollusc Scrobicularia } \\
\text { plana }\end{array}$ \\
\hline $\begin{array}{c}\text { SC05 (Poz- } \\
75199)\end{array}$ & $249-250$ & -6.4 & $1565 \pm 30$ & $1391-1531$ & TOC \\
\hline $\begin{array}{l}\text { SC05 (Poz- } \\
70618)\end{array}$ & $\begin{array}{c}350.5- \\
351.1\end{array}$ & -7.41 & $765 \pm 30$ & $668-731$ & $\begin{array}{l}\text { Mollusc Scrobicularia } \\
\text { plana }\end{array}$ \\
\hline $\begin{array}{l}\text { SC05 (Poz- } \\
75200)\end{array}$ & $570-571$ & -9.61 & $3630 \pm 35$ & $3844-3999$ & TOC \\
\hline $\begin{array}{l}\text { SC14 (Poz- } \\
74786)\end{array}$ & $43.5-44.5$ & $\begin{array}{c}- \\
13.14 \\
5\end{array}$ & $4050 \pm 35$ & $4423-4623$ & Plant debris \\
\hline $\begin{array}{l}\text { SC14 (Poz- } \\
75201)\end{array}$ & $\begin{array}{c}102.5- \\
103.5\end{array}$ & $\begin{array}{c}- \\
13.73 \\
5\end{array}$ & $5390 \pm 40$ & $6172-6287$ & TOC \\
\hline $\begin{array}{l}\text { SC14 (Poz- } \\
\quad 74787)\end{array}$ & $\begin{array}{l}241- \\
241.5\end{array}$ & $\begin{array}{c}- \\
15.11 \\
5\end{array}$ & $4670 \pm 35$ & $5314-5472$ & Plant debris \\
\hline $\begin{array}{c}\text { SC14 (Poz- } \\
74788)\end{array}$ & $\begin{array}{c}373.5- \\
374\end{array}$ & -16.44 & $4560 \pm 35$ & $5053-5189$ & Plant debris \\
\hline $\begin{array}{l}\text { SC14 (Poz- } \\
75202)\end{array}$ & $502-503$ & -17.73 & $5790 \pm 40$ & $6485-6676$ & TOC \\
\hline $\begin{array}{l}\text { SC17 (Poz- } \\
74789)\end{array}$ & $\begin{array}{l}555- \\
555.5\end{array}$ & $\begin{array}{c}- \\
15.05 \\
5 \\
\end{array}$ & $4650 \pm 35$ & $5310-5468$ & Plant debris \\
\hline
\end{tabular}

